OPEN ACCESS

Edited by:

Gelsomina Fico,

University of Milan, Italy

Reviewed by:

Guoqiang Gu,

Vanderbilt University, United States

Anne-Francoise Burnol,

INSERM U1016 Institut Cochin,

France

*Correspondence:

Ahmed Al-Harrasi

aharrasi@unizwa.edu.om

Natália Cruz-Martins

ncmartins@med.up.pt

Javad Sharifi-Rad

javad.sharifirad@gmail.com

Miquel Martorell

mmartorel/@udec.cl

${ }^{\dagger}$ These authors have contributed equally to this work

Specialty section:

This article was submitted to Diabetes: Molecular Mechanisms,

a section of the journal

Frontiers in Endocrinology

Received: 21 January 2021 Accepted: 31 March 2021

Published: 01 June 2021

Citation:

Ramírez-Alarcón K, Victoriano M, Mardones L, Villagran M, Al-Harrasi A, Al-Rawahi A, Cruz-Martins N, Sharifi-Rad J and Martorell M (2021)

Phytochemicals as Potential Epidrugs in Type 2 Diabetes Mellitus.

Front. Endocrinol. 12:656978.

doi: 10.3389/fendo.2021.656978

\section{Phytochemicals as Potential Epidrugs in Type 2 Diabetes Mellitus}

\author{
Karina Ramírez-Alarcón ${ }^{1 \dagger}$, Montserrat Victoriano ${ }^{1 \dagger}$, Lorena Mardones ${ }^{2}$, \\ Marcelo Villagran ${ }^{2,3}$, Ahmed Al-Harrasi ${ }^{4 *}$, Ahmed Al-Rawahi ${ }^{4}$, Natália Cruz-Martins ${ }^{5,6,7 *}$, \\ Javad Sharifi-Rad ${ }^{8,9 *}$ and Miquel Martorell ${ }^{1,10,11 *}$
}

${ }^{1}$ Department of Nutrition and Dietetics, Faculty of Pharmacy, University of Concepción, Concepción, Chile, ${ }^{2}$ Department of Basic Science, Faculty of Medicine, Universidad Catolica de la Santisima Concepcion, Concepción, Chile, ${ }^{3}$ ScientificTechnological Center for the Sustainable Development of the Coastline, Universidad Catolica de la Santisima Concepcion, Concepción, Chile, ${ }^{4}$ Natural and Medical Sciences Research Centre, University of Nizwa, Birkat Al Mouz, Oman, ${ }^{5}$ Faculty of Medicine, University of Porto, Alameda Prof. Hernâni Monteiro, Porto, Portugal, ${ }^{6}$ Institute for Research and Innovation in Health (i3S), University of Porto, Porto, Portugal, 7 Laboratory of Neuropsychophysiology, Faculty of Psychology and Education Sciences, University of Porto, Porto, Portugal, 8 Phytochemistry Research Center, Shahid Beheshti University of Medical Sciences, Tehran, Iran, ${ }^{9}$ Facultad de Medicina, Universidad del Azuay, Cuenca, Ecuador, ${ }^{10}$ Centre for Healthy Living, University of Concepción, Concepción, Chile, ${ }^{11}$ Universidad de Concepción, Unidad de Desarrollo Tecnológico, UDT, Concepción, Chile

Type 2 diabetes Mellitus (T2DM) prevalence has significantly increased worldwide in recent years due to population age, obesity, and modern sedentary lifestyles. The projections estimate that 439 million people will be diabetic in 2030. T2DM is characterized by an impaired $\beta$-pancreatic cell function and insulin secretion, hyperglycemia and insulin resistance, and recently the epigenetic regulation of $\beta$ pancreatic cells differentiation has been underlined as being involved. It is currently known that several bioactive molecules, widely abundant in plants used as food or infusions, have a key role in histone modification and DNA methylation, and constituted potential epidrugs candidates against T2DM. In this sense, in this review the epigenetic mechanisms involved in T2DM and protein targets are reviewed, with special focus in studies addressing the potential use of phytochemicals as epidrugs that prevent and/or control T2DM in vivo and in vitro. As main findings, and although some controversial results have been found, bioactive molecules with epigenetic regulatory function, appear to be a potential replacement/complementary therapy of pharmacological hypoglycemic drugs, with minimal side effects. Indeed, natural epidrugs have shown to prevent or delay the T2DM development and the morbidity associated to dysfunction of blood vessels, eyes and kidneys due to sustained hyperglycemia in T2DM patients.

Keywords: type 2 diabetes mellitus, hyperglycemia, protein target, epigenetic, epidrug, phytochemicals

\section{INTRODUCTION}

Type 2 diabetes Mellitus (T2DM) is a metabolic disorder associated with high morbi-mortality rates and expenses in the healthcare system at worldwide level (1). Featured by an insulin deficit triggered by the pancreatic dysfunction of $\beta$-type cells and insulin resistance in target organs (2), in 2014, the World Health Organization (WHO) referred that $8.5 \%$ of adults (18 years or older) had this disease, 
and that in 2015, 1.6 million people died as a direct result of T2DM. Even high blood sugar levels alone has been the cause of another 2.2 million deaths in 2012 (3).

The global increase in obesity, along with physical inactivity and energy dense diets (4), has triggered direct or epigenetic changes in phenotype that would be the cause of the disease (5). So, these environmental changes have been correlated with the large increase in the number of T2DM patients. Recently, it has been recognized that T2DM results from regulatory imbalances at both genetic and epigenetic levels. Currently it is known that epigenetics has an important role in the insulin secretion and action and T2DM development (6). The differentiation of $\beta$ pancreatic cells is controlled by several genes, such as GLP1 (glucagon-like peptide-1; stimulates insulin secretion and inhibits glucagon secretion), PAX4 (paired box gene 4; involved in pancreatic islet development) and PDX1 (pancreatic and duodenal homeobox 1; involved in pancreatic development, $\beta$-cell differentiation and the maintenance of mature $\beta$-cell function) receptor, with all these genes being regulated at the epigenetic level. In addition, some factors involved in insulin resistance, such as the nuclear factor kappa$\mathrm{B}(\mathrm{NF}-\mathrm{\kappa B})$, osteopontin and Toll-like receptors, are also epigenetically regulated (7). Human T2DM case-control studies and intervention studies in non-diabetic people showed epigenetic alterations of PDX1, CDKN1A (cyclin-dependent kinase inhibitor 1 ; involved in cell cycle regulation) and GLRA1 (glycine receptor alpha 1; down-regulation of neuronal excitability) genes which seem to contribute to diabetes (6). An increase in the level of DNA methylation of PDX-1 has been related to a reduced activity in pancreatic islets and a dysregulation of pancreatic $\beta$-cells in T2DM (8). CDKN1A overexpression decreases insulin secretion and proliferation (9) and GLRA1 silencing in clonal $\beta$-cells reduced glucosestimulated insulin secretion (10). In addition, physical activity alter DNA methylation of T2DM gene candidates such as FTO (fat mass and obesity-associated protein; associated with energy intake) and TCF7L2 (transcription factor 7-like 2; blood glucose homeostasis) in adipose tissue (6). In obese humans after a metabolic surgery, epigenetic and metabolic changes were reported in skeletal muscle during the improvement of insulin sensitivity (11). The major sign of uncontrolled diabetes is hyperglycemia, and when it is maintained for prolonged periods, results in the blood vessels destruction, that consequently triggers damages to the heart, eyes, kidneys and central nervous system (CNS) (12). As a result, both macrovascular (atherosclerotic) and microvascular (retinopathy and nephropathy) disorders occur. These complications are the main causes of mortality in diabetic patients. In this sense, intensive lifestyle modification, pharmacotherapy or both have been proposed, as they are able to reverse or delay the T2DM complications (2). Studies have reported an increased use of natural products in patients with T2DM (13-15); this is due to the long-term use of oral hypoglycemic agents and insulin, characterized by numerous side effects, that include episodes of hypoglycemia, gastrointestinal problems (nausea, vomiting and diarrhea), edema and even hepatorenal disorders $(16,17)$. The therapeutic activity of these plants, used as food or infusions, depends on the interaction of several kinds of phytochemicals. Actually, there are more than 1,200 species of medicinal plants with antidiabetic activity, and of these approximately 200 pure bioactive compounds possess potent hypoglycemic properties (18) and have an important role in histone modification and DNA methylation (19). In this sense, here we aim to discuss the epigenetic mechanisms involved in diabetes and protein targets, also giving a special emphasis to in vitro and in vivo studies and clinical trials, addressing the phytochemicals with epidrug potential in diabetes.

\section{EPIGENETIC MECHANISMS OF TYPE 2 DIABETES MELLITUS}

The hyperglycemia occurring in T2DM is a systemic alteration that affects all tissues leading to long-term diseases (20). Particularly, hyperglycemia is able to alter the expression of genes involved in insulin resistance, low grade systemic inflammation and renal fibrosis (21). The biological process underlying the changes in gene expression comprises the epigenetic regulation of the genome of different tissues including skeletal muscle, liver, pancreas, blood and adipose tissue for T2DM (22). The physical basis of the epigenetic regulation are changes in the chromatin structure without changes in DNA sequence, some of them could even be transmitted through generations. Globally, the epigenetic modifications can be grouped into three categories: DNA methylation, posttranslational histone modifications and noncoding RNAs (23).

\section{General Epigenetic Mechanisms}

Methylation of DNA was the first epigenetic mechanism discovered and is associated to transcriptional genes silencing, whose promoter has been methylated. It consists in the covalent attachment of a methyl group at the 5' carbon of cytosine residues in a promoter region rich in cytosine-phosphateguanine $(\mathrm{CpG})$, called $\mathrm{CpG}$ islands (24). The presence of these modified nucleotides is able to recruit methyl-CpG binding proteins that promote chromatin condensation and, therefore, restrict the accessibility of transcription factors and the general transcription machinery to the promoter (24). The DNA methyltransferases (DNMTs) are a family of enzymes that catalyze the methyl transfer from S-adenosylmethionine (SAM) to cytosine and are composed of DNMT1, DNMT3A and DNMT3b. The removal of the methyl group is accomplished by demethylases of the ten eleven translocation (TET) family, which mediates an oxidation of the methyl group that renders a 5 -hydroxymethylcytosine that is later replaced by cytosine during DNA repair. DNA demethylation counteracts the chromatin compaction elicited by methyl marks and is usually linked to transcriptional activation (25). DNMT3A was reported as epigenetic mediator of adipose insulin resistance in mouse and human adipocytes (26). 
Post-translational histone modifications are a diverse group of covalent modification generally located in the N-terminal. Briefly, the acetylation, methylation, phosphorylation and ubiquitination of specific residues are among the most studied, but there is an emerging number of up to 67 newly identified histone modifications with the potential of regulating gene expression (27). First, histone acetylation occurs in lysine residues and activates gene transcription through chromatin de-condensation and acts as a binding site for transcriptional activators. Histone acetyl transferases (HAT) catalyze acetylation and so stimulate gene transcription, whereas histone deacetylases (HDACs) remove the acetyl group from histones, promoting the transcriptional repression (28). Methylation of histones takes place in lysine and arginine residues and each residue could present different methylation states, including mono, di and trimethyl lysine, while arginine may be symmetric or asymmetrically mono or dimethylated. Depending on the specific residue and the methylation state, transcription effect could be activated or repressed. For example, the mono, di or trimethylation of histone $\mathrm{H} 3(\mathrm{H} 3)$ at Lys4 $(\mathrm{H} 3 \mathrm{~K} 4 \mathrm{~m} 1 / 2 / 3)$ have been associated with transcriptionally active genome regions, while trimethylation of $\mathrm{H} 3$ at Lys9 or at Lys27 (H3K9m3/ $\mathrm{H} 3 \mathrm{~K} 27 \mathrm{~m} 3)$ and trimethylation of $\mathrm{H} 4$ at Lys20 (H4K20m3) are abundant in silenced DNA regulatory elements (29). Second, histone methylation is carried out by histone methyltransferases (HMTs) of different specificity for lysine or arginine, with methyl removal depending on the action of demethylases with defined specificity as well. Other emerging histone modifications relevant for T2DM are crotonylation and $\beta$-hidroxybutyrilation, both affecting lysine residues $(30,31)$. Finally, gene expression can also be regulated transcriptionally and post-transcriptionally by noncoding RNA molecules. Among them, miRNAs are typically composed of 21 to 23 nucleotides long and mediate posttranscriptional repression through binding to complementary regions of specific target mRNAs, leading to its degradation by the RISC complex (32). Another relevant non coding RNA for T2DM are long non-coding RNAs (lncRNAs) involved in recruitment of DNMTs and histone modifiers to their target genes and, particularly the eRNAs, facilitate promoter-enhancer looping, thus increasing the transcription rate of neighboring genes (33).

\section{Epigenetic Alterations in T2DM DNA Methylation}

T2DM is a complex metabolic disease in which many interconnected pathologic mechanisms ensue. Initial studies analyzed DNA methylation of candidate genes for T2DM such as INS (insulin), PDX1, PPARGC1A (PGC1 $\alpha$; transcriptional co-activator), and GLP1R (GLP1 receptor) in human pancreatic islets from donors with TD2M and non-diabetic controls $(22,34$, 35). In these studies, islets from T2DM donors were found to have increased DNA methylation and decreased expression of these key genes associated with impaired insulin secretion (22). In addition, the increase of DNA methylation of these genes seemed to directly be associated with high glucose and glycated hemoglobin (HbA1c) levels. In pancreatic islets, early molecular alterations occur and mediate islet dysfunction before the onset of diabetes (36). DNA methylation patterns of $\beta$-cell are dynamic during maturation and T2DM onset and evolution (37). Some differentially methylated regulatory elements have been associated with key function genes such as PDX1, TCF7L2 and NKX6-1 (homeobox protein Nkx-6.1; regulation of islet transcription factors and genes involved in glucose and insulin homeostasis). In Langerhans Islets from obese mice which differed in their degree of hyperglycemia and in liver fat content a semi-explorative approach identified 497 differentially expressed and methylated genes linked to insulin secretion and extracellular matrix-receptor interaction (38). In addition, the comparison of mouse data with DNA methylation levels of TD2M participants of European Prospective Investigation Cancer (EPIC)-Potsdam cohort revealed 105 genes with altered DNA methylation at $605 \mathrm{CpG}$ sites, which were associated with future T2DM. The first epigenome-wide association studies of DNA methylation markers of obesity and T2DM are helping to gain a comprehensive insight into the global epigenetic alterations related to the onset of T2DM. In samples of blood cells of 5,387 individuals, changes in methylation markers of genes involved in lipid metabolism, substrate transport and inflammatory pathways have been reported (39). In addition, although these changes have been detected in a non-metabolically relevant tissue, similar DNA methylation abnormalities were also detected in adipose, muscle and liver tissue samples of a small subset of participants. Interestingly, the DNA methylation disturbances induced by obesity can predict future development of T2DM $(22,39)$. Another study conducted in the same population, developed a prospective nested-control study that analyzed genome-wide DNA methylation markers in blood cells of participants before the T2DM onset. DNA methylation markers at five genes: ABCG1 (ATP-binding cassette sub-family G member 1; regulates cellular lipid homeostasis, including pancreatic $\beta$ cells), PHOSPHO1 (phosphatase, orphan; involved in bone mineralization), SOCS3 (suppressor of cytokine signaling 3; negative regulator of insulin signaling), SREBF (sterol regulatory element binding transcription factor 1; regulator of hepatic lipogenesis) and TXNIP (thioredoxin interacting protein; key component of pancreatic $\beta$ cell biology, nutrient sensing, energy metabolism and regulation of cellular redox) have been associated with up to four times higher risk of future T2DM (40), so that these markers raise the possibility to identify normoglycemic subjects that could benefit from early pharmacological or lifestyle interventions to prevent the T2DM development (40). Besides these genomic-wide studies of DNA methylation markers in T2DM, several other studies have focused on the epigenetic markers of specific genes in the context of particular pathogenic events related to T2DM. In this regard, chronic inflammation has been recognized as a key pathologic feature of T2DM, accompanied by DNA methylation changes. In blood mononuclear cells from T2DM patients, the methylation level at the $\mathrm{CpG}$ sites of the monocyte chemoattractant protein (MCP)-1 promoter is decreased, and associated to an overexpression of this chemotactic factor in 
serum (41). A similar decreased in DNA methylation was found at interleukin (IL)-1 $\beta$ promoter in blood cells and at 3'UTR of TXNIP in skeletal muscle from T2DM patients $(42,43)$. In other study, increased methylation and decreased expression of PPARGC1A were reported in skeletal muscle from TD2M humans and when this gene was silenced in human islets, insulin secretion was decreased (44).

\section{Histone Tail Modifications}

Alterations in the multiple types of histone modifications have also been implicated among the epigenetic mechanisms underlying T2DM inflammation. Studies mainly developed in cell models have reported changes in histone marks within regulatory elements of inflammation genes in response to hyperglycemia. For example, Miao and Gonzalo (45) found an increase of histone acetylation at NF- $\kappa$ B promoter in THP-1 monocytes induced by a transient exposure to high levels of glucose. The higher acetylation was correlated to increased recruitment of p300/CBP-associated factor (PCAF) to NF- $\kappa \mathrm{B}$ promoter and overexpression of proinflammatory target genes, like cyclooxygenase-2 (COX-2) and tumor necrosis factor (TNF) (45). Interestingly, similar changes in histone modification of $\mathrm{NF}-\kappa \mathrm{B}$ have been stated in monocytes from T2DM subjects, showing an in vivo correlate of the epigenetic changes (45). IL-8 is another proinflammatory gene whose overexpression is induced by hyperglycemia in human primary vascular cells by an epigenetic mechanism involving hyperacetylation of its promoter region (46). Ibarra Urizar and Prause (47) hypothesized that prolonged exposure of $\beta$-cells to IL- $1 \beta$ induce $\beta$-cell dedifferentiation characterized by impaired glucose-stimulated insulin secretion, reduced expression of key $\beta$-cell genes and changes in histone modifications. In their study they observed that IL-1 $\beta$ at low concentration induces epigenetic changes associated with loss of $\beta$-cell identity as observed in T2DM. The epigenetic effect of hyperglycemia is not limited to induction of hyperacetylation but also triggers $\mathrm{H} 3 \mathrm{~K} 4$ hypermethylation and $\mathrm{H} 3 \mathrm{~K} 9$ hypomethylation in NF- $\mathrm{KB}$ p65, leading to a persistent upregulation in endothelial cells under hyperglycemic conditions. These changes in histone methyl marks are mediated by the recruitment of SETD7 (SET domain containing 7 , histone lysine methyltransferase) and lysine-specific demethylase 1 (LSD1) to NF- $\kappa$ B promoter and are linked to a higher expression of NF- $\kappa \mathrm{B}$ regulated genes, like MCP-1 and vascular cell adhesion protein 1 (VCAM) (48). In addition, the ex vivo methylation changes of NF- $\kappa \mathrm{B}$ p 65 in endothelial cells have also been shown in blood mononuclear cells of T2DM patients, where the unbalance is also related to an increased expression of MCP-1, intercellular adhesion molecule (ICAM)-1 and COX-2 (49). Similarly, the increased expression of IL-8 in endothelial cells is not only mediated by higher histone acetylation but also by $\mathrm{H} 3 \mathrm{H} 4$ hypermethylation induced by SETD7 methylase (50). These examples underline that hyperglycemia induce an overexpression of proinflammatory genes by redundant epigenetic histone marks, that in the case of NF- $\kappa B$, additionally involve acetylation of lysine residues of transcription factor itself (51). Other relevant overexpression states of proinflammatory genes mediated by methylation changes related to hyperglycemic stimulus are the IL-6 and MCP-1 in vascular smooth muscle cells, IL-6 in rat cardiomyocytes, IL-12 subunit beta (IL-12B), macrophage inflammatory protein (MIP)-1 $\alpha$, MIP-1 $\beta$, and IL-6 in THP-1 monocytes (52).

\section{Non-Coding RNA}

Post-transcriptional repression mediated by miRNA also contribute to the dysregulation of proinflammatory gene expression in T2DM, usually mediating the accelerated mRNA decay of transcriptional activators of inflammatory mediators. An increased expression of miR-125b in vascular smooth muscle cells has also been reported in a T2DM mouse model (53). The higher levels of miR-125b triggers a decrease in the SUV39H1 histone methylase levels, leading to a reduction of the $\mathrm{H} 3 \mathrm{~K} 9$ activating signal in the promoters of IL-6 and MCP-1 (53). Other miRNAs upregulations in T2DM impacting the proinflammatory genes expression are: miR-146a decreasing the expression TNF receptor-associated factor 6 (TRAF6) and interleukin 1 receptor-associated kinase 1 (IRAK1); miR-200c family members increasing the expression of COX-2 and MCP-1; and miR-504 increasing the expression of IL-6, COX2 and MCP1 (52). Abnormalities of IncRNA have also been observed in T2DM-associated inflammation. For example, the E33 lncRNA levels were increased in macrophages of a mouse model of T2DM as well as the human homolog MIR143HG $(54,55)$. However, only partial data is now available related to the mechanism of deregulation, but an induction of several proinflammatory genes, like IL-6, TNF and COX-2, whereas the downregulation of MCP-1 and of anti-inflammatory IL-10 has been reported (55). Sathishkumar and Prabu (56) related that metastasis-associated lung adenocarcinoma transcript 1 (MALAT1) is another IncRNA that may regulate the T2DMrelated inflammation through upregulation of serum amyloid antigen (SAA), ultimately inducing IL-6 and TNF in human umbilical vein endothelial cells (HUVECs).

\section{PHYTOCHEMICAL REGULATION OF PROTEIN TARGETS FOR THE TREATMENT OF DIABETES}

The treatment of T2DM is usually focused in the regulation of protein target activities (7). Several phytochemicals from fruits, vegetables, spices, teas, and medicinal plants may regulate epigenome and exhibit low toxicity in chronic administration (57). The applicability of major phytochemical groups such as polyphenols, terpenoids, organosulfur and alkaloids as epidrugs is experimentally established $(58,59)$. In this section, the common protein targets for T2DM treatment and phytochemicals that modulate the activities of these proteins with antidiabetic activities in in silico, in vitro and in vivo studies are presented, while data related to clinical trials is shown in Table 1. 
TABLE 1 | Clinical trials related to natural epidrugs to treat Type 2 Diabetes Mellitus.

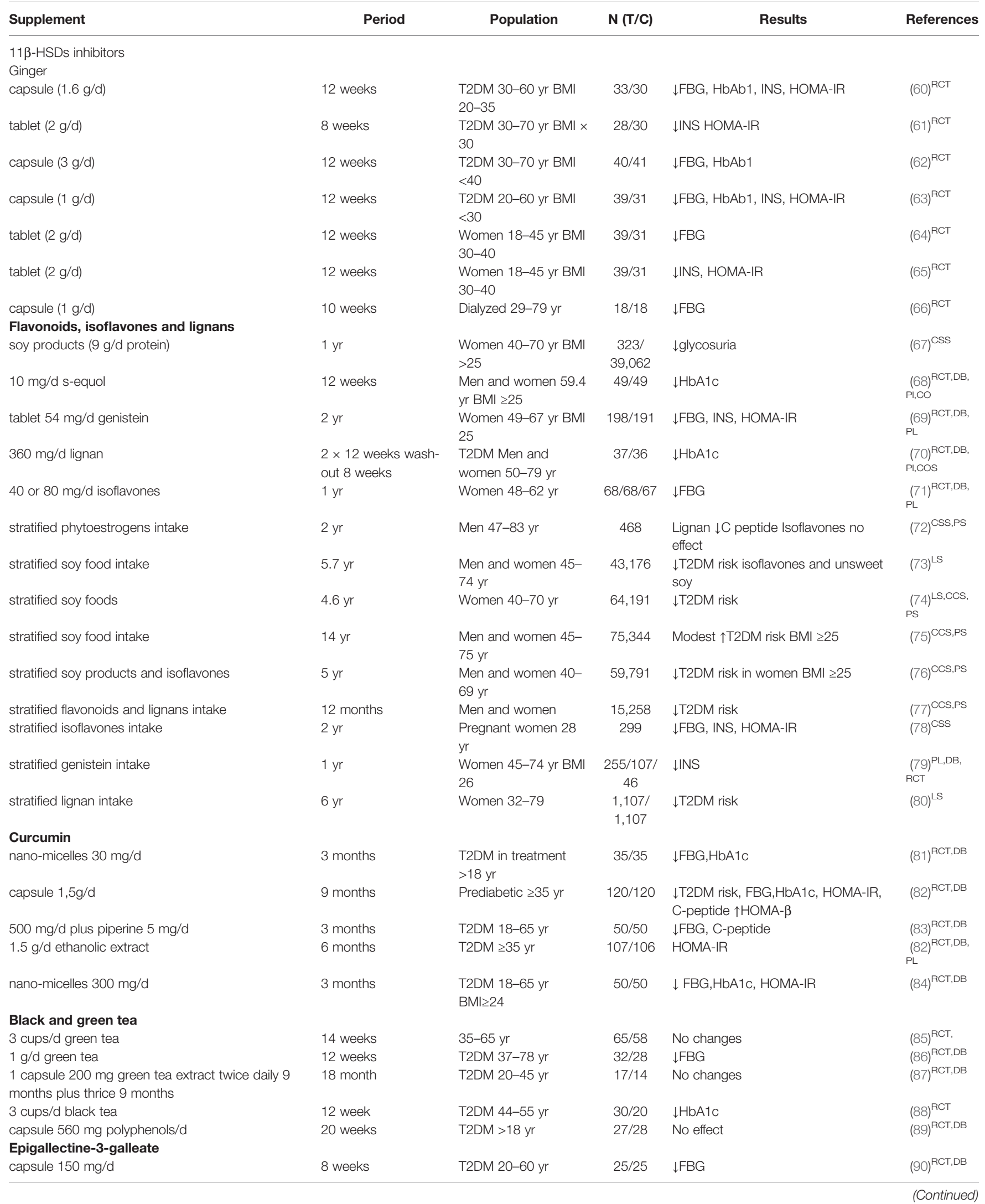


TABLE 1 | Continued

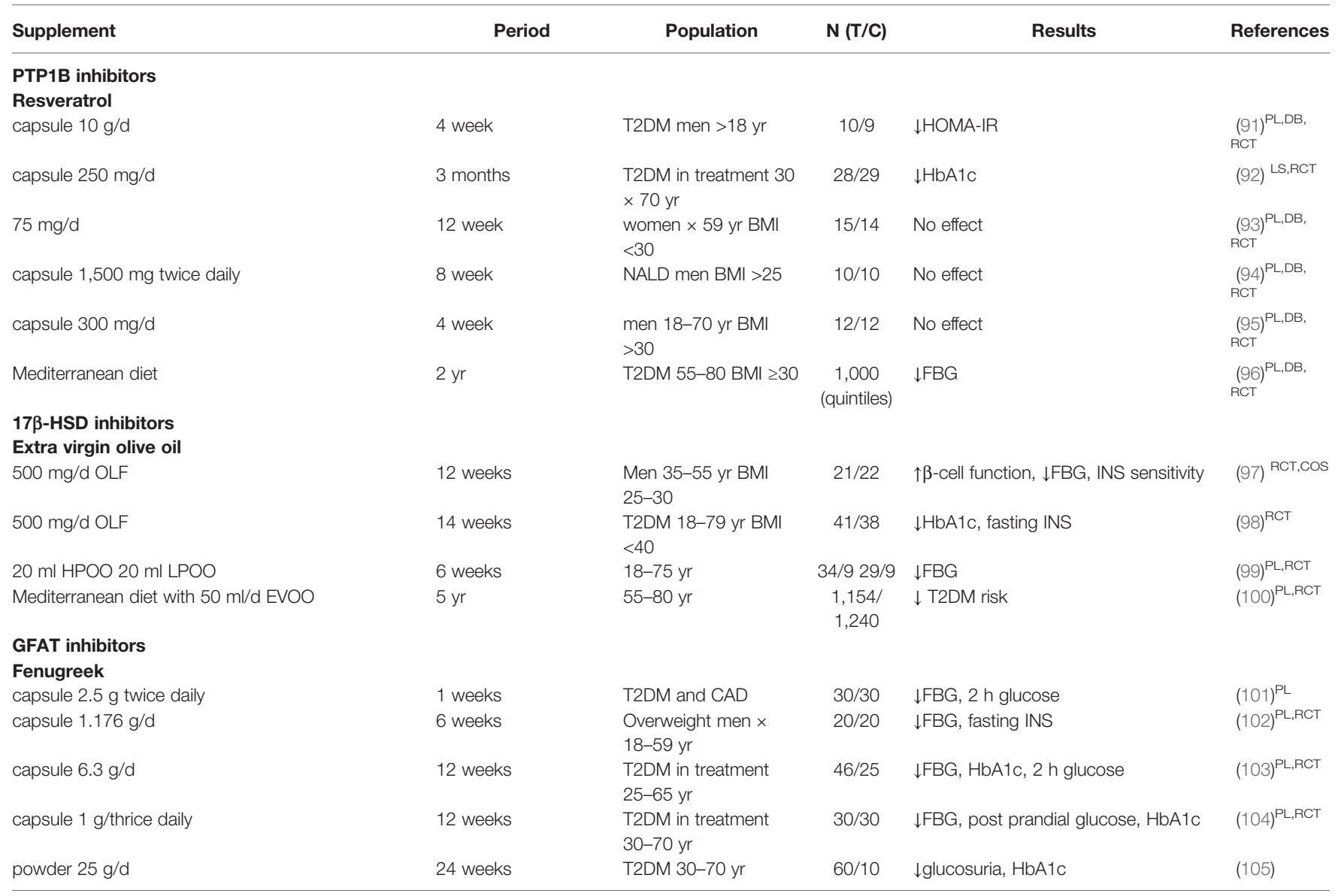

BMI, body mass index ( $\left.\mathrm{kg} / \mathrm{m}^{2}\right)$; CAD, coronary arterial disease; CCS, case-cohort study; COS, cross-over study; CSS, cross-sectional study; DB, double-blind; FBG, fast blood glucose; T2DM, type 2 Diabetes Mellitus; HbA1C, glycosylated hemoglobin; INS, insulin; IR, insulin resistance; HOMA, Homeostasis Model Assessment; HPOO, high phenolic extra virgin olive oil; LPOO, low phenolic olive oil; LS, longitudinal study; NALD, no-alcoholic liver disease; OLF, olive leaf extract; PL, parallel trial; PPG, postprandial glucose; PS, prospective study; RCT, randomized clinical trial; T/C, treated $\mathrm{v} / \mathrm{s}$ control.

\section{Decrease Insulin Resistance via 11 $\beta$ - Hydroxysteroid Dehydrogenase Inhibition}

Cortisol plays an important role in metabolism and T2DM, and the inhibition of the hepatic glucocorticoid receptor was found to reduce the serum glucose levels in T2DM mice while improve the insulin resistance (106). Indeed, an abnormal glucocorticoid metabolism has been linked to T2DM (107). Specifically, the $11 \beta$-hydroxysteroid dehydrogenase $(11 \beta$-HSDs) is an oxidoreductase enzyme that catalyzes the conversion of inert 11 keto-products (cortisone, 11-dehydrocorticosterone) to active glucocorticoids (corticosterone, cortisol). 11 $\beta$-HSD1 regulates cortisol levels mainly in adipose, hepatic and brain tissues (108). Briefly, 11ß-HSDs has several isoforms in humans, where $11 \beta-H S D 1$ is a NADPH-dependent isoform highly expressed in key metabolic tissues of liver, adipose, pancreas, and skeletal muscle (109), while 11ß-HSD is a potent therapeutic target whose inhibition may be useful for the treatment of $\operatorname{T2DM}(107,110)$.

A high enzyme activity of $11 \beta$-HSD1 is related with the development TD2M and others metabolic disorders and the inhibition of this enzyme attenuate the development of T2DM, insulin resistance, metabolic syndrome and other diseases mediated by excessive cortisol production (108).

Zhu and Ge (111) in a study compared the ability of flavonoids and isoflavonoids to inhibit human $11 \beta-\mathrm{HSD} 1$ and $11 \beta-\mathrm{HSD} 2$. Briefly, the authors found that apigenin, quercetin, genistein and ( \pm )-equol were able to inhibit human $11 \beta$-HSD1, with $\mathrm{IC}_{50}$ values of $2.2,5.4,11.0$, and $>100 \mu \mathrm{M}$, respectively. However, apigenin and $( \pm$ )-equol were not able to inhibit $11 \beta$-HSD2 at doses as high as $100 \mu \mathrm{M}$, while genistein and quercetin inhibited it by 60 and $50 \%$ at $100 \mu \mathrm{M}$, respectively (111). In streptozotocinnicotinamide induced diabetic rats, quercetin showed antidiabetic activity acting as $11 \beta$-HSD1 inhibitor (112). Moreover, genistein suppressed $11 \beta$-HSD1 in rodent adipose tissue and blocked the glucocorticoid amplification (113). However, in male ob/ob mice a diet rich in genistein $(600 \mathrm{mg} /$ $\mathrm{kg}$ ) for 4 weeks reduced hypercorticosteronism, decreasing protein expression of renal $11 \beta-H S D 2$ without changes in hepatic $11 \beta$-HSD1 (114).

Teich and Pivovarov (115) assessed the inhibitory action on $11 \beta$-HSD1 activity of curcumin on preserving metabolic health 
and limiting adipose tissue growth following the cessation of daily exercise and caloric restriction $(50-65 \%$ of ad libitum intake) in Sprague-Dawley rats. As main findings, the authors stated that curcumin $(200 \mathrm{mg} / \mathrm{kg})$ significantly reduced insulin, homeostasis model assessment-insulin-resistance (HOMA-IR), and C-reactive protein levels, and also exhibited inhibitory activity against human and rat $11 \beta$-HSD1 in intact cells $\left(\mathrm{IC}_{50}=\right.$ 2.3 and $5.8 \mu \mathrm{M}$, respectively) and on $11 \beta$-HSD2 $\left(\mathrm{IC}_{50}=14.56\right.$ and $11.92 \mu \mathrm{M}$, respectively) (116). Also, curcumin (200 mg/kg) reduced serum glucose, cholesterol, triglyceride, low density lipoprotein levels in high-fat-diet-induced obese rats (116).

Resveratrol is a plant-derived polyphenolic compound and a potent antioxidant. The effects of resveratrol on $11 \beta$-HSD1 activity in rodent adipose tissue was studied by Tagawa and Kubota (117). In this study, the $11 \beta$-HSD1 activity by resveratrol was inhibited $\left(\mathrm{IC}_{50}\right.$ value of $35.2 \mu \mathrm{M}$ ) but resveratrol did not affect the activities of $11 \beta$-HSD2 and hexose-6-phosphate dehydrogenase. Several teas (Camellia sinensis (L.) Kuntze) and tea specific polyphenolic compounds were also tested in human liver microsomes and purified human $11 \beta$-HSD 1 for their possible antidiabetic potential via cortisone reduction by $11 \beta$-HSD1 inhibition (118). The polyphenol (-)-epigallocatechin gallate (EGCG) exhibited the strongest inhibition of $11 \beta-H S D 1\left(\mathrm{IC}_{50}=57.99 \mu \mathrm{M}\right.$ for reduction; $\mathrm{IC}_{50}=$ 131.2 $\mu \mathrm{M}$ for oxidation).

In a systematic review and meta-analysis of 10 short and small-size randomized controlled trials, ginger (Zingiber officinale Roscoe) has also demonstrated good ameliorative effects in fasting blood glycemia (FBG), insulin, HOMA-IR and HbA1c (1-3 g/day for 4-12 week, $\mathrm{n}<40$ ) control and insulin sensitivity (119). In particular, in two studies, T2DM patients decreased FBG, HbA1c, insulin and HOMA-IR after receive a daily capsule with 1.6 or $1 \mathrm{~g}$ /day of ginger, respectively. In the first study, 33 subjects received the treatment and 30 were controls (60), meanwhile in the second one, the sample were 39 subjects and the control 31 (63). Moreover, specifically, the three gingerol derivatives, namely paradol, (E)-shogaol, and (5R)-acetoxy-gingerol, were able to inhibit human and mouse $11 \beta$-HSD1 activities $\left(\mathrm{IC}_{50}\right.$ values ranged between 1.09 and 1.30 $\mu \mathrm{M})$ (120). Licorice (Glycyrrhiza glabra L.) is a plant that has been increasingly studied for its antidiabetic potential (121) and has shown pre-translational inhibitory effects of $11 \beta$-HSD in vitro (rat pituitary $\mathrm{GH} 3$ cells) and in vivo (rats, $75 \mathrm{mg} / \mathrm{kg} /$ day glycyrrhizic for 5 days) (121).

Gumy and Thurnbichler (122) also investigated the ability of some medicinal plants extracts to inhibit $11 \beta$-HSD 1 in transfected HEK-293 cells. As main findings, the authors found that leave extracts of loquat (Eriobotrya japonica (Thunb.) Lindl.) and extracts of roasted but not coffee beans were capable of inhibiting $11 \beta$-HSD1. Concomitantly, there have been several clinical studies exploring the effect of natural inhibitors of $11 \beta$-HSD1 in T2DM, principally soy isoflavones, despite some of them are still in process. In general, results are inconsistent, mainly because of the small sample size, different characteristics of enrolled population, source and doses of administration or the use of other molecules in combination.
There are several meta-analysis of clinical studies related to beneficial effect of flavonoids, lignans and isoflavones intake in decreasing T2DM risk or improving biochemicals parameters of glucose metabolism $(123,124)$. For example, a daily intake of soy product with $9 \mathrm{~g}$ of protein for 1 year in 323 overweight postmenopausal women (control 39,062 women), decreased glycosuria (67). Moreover, the intake of $10 \mathrm{mg}$ of s-equol for 12 weeks in 49 women and men (control 49 subjects), decreased HbA1c (68). Similar effect showed the administration of $360 \mathrm{mg} /$ day flaxseed-derived lignan supplement in 37 T2DM patients (control 36 subjects) in two periods of 12 weeks each one (70). In the case of genistein, the administration of $54 \mathrm{mg} /$ day for 2 years in 198 post-menopausal women (control 191 women) reduced fasting insulin levels and also improved FBG and HOMA-IR (69). Also isoflavones intake showed beneficial effect in postmenopausal women, at doses of 40 and $80 \mathrm{~g} /$ day for a year, decreasing 5.2 and $3.3 \mathrm{mg} / \mathrm{dl}$ FBG, respectively $(\mathrm{n}=68$ each experimental group, control $\mathrm{n}=67$ ) (71).

Also, there are long long longitudinal studies that evaluated the beneficial effect of soy food, phytoestrogens, flavones, isoflavones and lignans consume. A small study performed in 468 men stratified according to phytoestrogen intake for two years, showed that lignan intake decreased C-peptide level, but isoflavones do not had effect (72). Other study performed in 299 pregnant women followed for 2 year of National Health and Nutrition Examination Survey-US, found an inverse relation between isoflavones intake and FBG, insulin and HOMA-IR (78). Goodman-Gruen and Kritz-Silverstein (79) analyzed the genistein intake in post-menopausal women for 1 year and founded an inverse relation with fasting insulin. Date from six cohort studies were also used to analyze the effect of soy foods, flavonoids, isoflavones and lignans. Zamora-Ros and Forouhi (77) found lower risk of T2DM associate to higher intake of flavonoids and lignans in 15,258 men and women of EPIC-InterAct study followed for a year. In date of the Nurses' Health Study (NHS) I and II, lignan intake for 6 year was associated to lower risk of T2DM in 1,107 women over 1,107 control (80). Moreover, when soy food intake was analyzed in 43,176 men and women from Singapore Chinese Health Study, followed for 5.7 years, only isoflavones and unsweet soy food were associated to lower risk of T2DM, meanwhile sweated soy food was associate to higher risk (73). In date from Japan Public Health Center-Based Prospective Study, in 59,791 men and women followed for 5 years, consume of soy products and isoflavones reduced the risk of T2DM in overweight-obese women (76). Finally, in 64,191 postmenopausal women of Shangai Women's Health Study, soy food reduced risk of T2DM when is consumed for 4.6 years (74).

In summary, case-control and prospective cohort studies suggest inverse associations between the total flavonoids, isoflavones and lignans intake with T2DM risk, and improvement of the disease development, with different effectiveness. Taken together, the findings evidence that there are other compounds in soy, such as lipids and fiber, than can have glycemic effect or can interact with flavone and that is necessary to measure specific phytoestrogen biomarkers to study its relationship with T2DM risk. 
There are also some few clinical trials addressing the role of curcumin in T2DM. In a small meta-analysis, three out of five randomized clinical trials, it was stated a reduction in FBG, HOMA-IR and HbA1c, in doses between 250 and 1,000 mg and treatment between 10 days and 9 months (124). In the longest study (9 months, 120 treated and 120 controls), curcuminoidstreated prediabetic subjects ( $1.5 \mathrm{~g} /$ day) did not develop T2DM, meanwhile in placebo group, $16 \%$ developed T2DM (82). Treated group also showed lower C-peptide and higher HOMA- $\beta$, revealing improvements in $\beta$ cell function. Moreover, in T2DM patients (50 treated and 50 controls), curcuminoids (500 mg/day for 3 months) decreased FBG, C-peptide and HbAlc (83). Other meta-analysis (125) showed that when curcumin was administrated in nano-micelles $(300 \mathrm{mg} /$ day for 3 months, $\mathrm{n}=$ 50 for treated and control T2DM subjects), FBG reduced $18 \%$ and HbAlc 11\% (84), similar result were obtained when $30 \mathrm{mg} /$ day were administrated for 3 months $(n=35$ for treated and control T2DM groups) (81). In addition, one out of three studies that analyzed renal function in T2DM patients, found beneficial effect of curcumin (125). Curcumin has rapid metabolism and low intestinal absorption, for that, micelles, nanoparticles, liposomes and phospholipid complexes have been used in some studies to improve its bioavailability and biological efficacy (124). Moreover, a differential gender-bioavailability has been reported, related to a higher hepatic metabolization of curcumin in men and effect of body fat in women, which could be consider in future studies (126).

Finally, there are some preclinical and clinical studies exploring the effect of green and black tea in T2DM. Studies were performed between 12 weeks and 18 months with doses/ day between $200 \mathrm{mg} /$ day and $2.5 \mathrm{~g} / 3$ times for day (127). For example, in a clinical trial for 12 weeks performed in $32 \mathrm{~T} 2 \mathrm{DM}$ patients and 28 controls, $1 \mathrm{~g} /$ day of green tea infusion reduced HbA1c $(86,88)$. But, in other four studies, no changes were observed after green tea administration when the intervention was shorter, as in Toolsee, Aruoma (85) study (4 weeks, 3 cups/ day, $\mathrm{n}=65$ and control $\mathrm{n}=58)(127)$. However, when three $(\mathrm{n}=$ $24)$ or $4(n=25)$ cups of green tea were administrated for 4 weeks in T2DM subject (control $\mathrm{n}=14$ ), systolic and diastolic blood pressure were decreased, with other four similar studies also evidencing significant improvements in both blood pressure and anthropometric data in T2DM patients $(128,129)$. Noteworthy, despite studies reveal controversial results related to effect of tea in T2DM, with an evident importance of the duration of the intervention, should be underlined that green tea also has flavan3-ols, that by itself have shown beneficial effects in clinical trials with hypertense, diabetic and overweight subjects (130). Finally, few human studies relating EGCG intake with T2DM have been done, with only a clinical trial finished (25 treated and 25 control T2DM subjects) found that $300 \mathrm{mg}$ of EGCG/day for 8 weeks significantly reduced FBG (90).

\section{Enhance Insulin Activity via Protein Tyrosine Phosphatase 1B Inhibition}

The improvement in insulin sensitivity is a key therapeutic strategy in T2DM. Protein tyrosine phosphatase 1B (PTP1B) inhibitors improve the insulin receptor sensitivity and, in the latter years, targeting PTP1B inhibitors is being considered an attractive target to treat T2DM (131). Binding of type 1 insulinlike growth factor (IGF-1) to its tetrameric receptor induces the auto-phosphorylation of the receptor, the downstream activation of protein kinase $\mathrm{B}(\mathrm{PKB})$ and mitogen-activated protein kinases (MAPK) pathways triggering the GLUT4 transporter translocation to the plasma membrane (132).

Natural products possessing inhibitory activities against PTP1B were reviewed by Jiang and Liang (133). In their work, the authors provide an overview of approximately 300 secondary metabolites that were isolated from various natural sources or derived from synthetic process. Among them, the phytochemicals targeting PTP1B include phenolics, terpenes, steroids, N- or S-containing compounds, and miscellaneous phytochemicals.

For example, resveratrol (dose equivalent at $2.5 \mathrm{mg} / \mathrm{kg}$ orally administered via drinking water) improved peripheral insulin signaling independently of Sirt1 in diabetic mice in association with PTP1B inhibition (134). Sirt1 is one of seven mammalian orthologs of the yeast protein, and has been suggested to be involved in the processes of glucose homeostasis and insulin secretion (135). Indeed, several studies have shown association of the effect of resveratrol in both proteins together (PTP1B and Sirt1) $(136,137)$.

Chuang and Martinez (138) showed that quercetin is more effective than resveratrol in inhibiting $\mathrm{PTP} 1 \mathrm{~B}$ in primary cultures of human adipocytes treated with TNF- $\alpha$. Indeed, the treatment with quercetin decreased the mRNA levels of PTP1B, while resveratrol treatment had no effect on PTP1B expression (138).

Curcumin and cinnamaldehyde decreased PTP1B enzymatic activity in breast cancer MCF-7 cell line (139), despite curcumin was more effective than cinnamaldehyde. Briefly, curcumin inhibited PTP1B at concentrations starting from $1 \mu \mathrm{M}\left(\mathrm{IC}_{50} \approx\right.$ $100 \mu \mathrm{M})(139)$. In fructose-fed rats, curcumin ingestion inhibited PTP1B and improved insulin and leptin sensitivity in the liver of rats, also protecting hypertriglyceridemia and hepatic steatosis induced by fructose diet (140). Also, it has been suggested that curcumin activate miRNA206 and then improve insulin sensibility (141).

Papaverine from Papaver somniferum L. is an isoquinoline alkaloid with inhibitory effects against PTP1B in humans (142). In vitro papaverine illustrated potent in vitro inhibitory effects against recombinant h-PTP1B $\left(\mathrm{IC}_{50}=1.20 \mu \mathrm{M}\right)$, while in vivo it led to a marked decreased in fasting blood glucose level in Balb/c mice (142).

$\mathrm{Xu}$ and Wang (143) studied anti-diabetic effect of bis(2,3dibromo-4,5-dihydroxybenzyl) ether (BDDE), a bromophenol isolated from the red alga (Odonthalia corymbifera). The in vitro treatment with $2.5,5$, or $10 \mu \mathrm{M}$ of BDDE for $16 \mathrm{~h}$ dosedependently inhibited the over-expression of PTP1B in insulinresistant HepG2 cells. In vivo in $\mathrm{db} / \mathrm{db}$ mice model, the BDDE activity was compared with that of metformin, where a significant decrease in blood glucose levels and HbAlc were stated following BDDE treatment, without weight gain (143).

Inhibitory activity of lipophilic compounds from Salvia miltiorrhiza Bunge roots against $\mathrm{PTP} 1 \mathrm{~B}$, was also investigated (144), being shown PTP1B inhibitory effects using cryptotan shinone $\left(\mathrm{IC}_{50}=5.5 \pm 0.9 \mu \mathrm{M}\right)$, tanshinol B $\left(\mathrm{IC}_{50}=4.7 \pm 0.4 \mu \mathrm{M}\right)$ 
and dehydrodanshenol $\left(\mathrm{IC}_{50}=8.5 \pm 0.5 \mu \mathrm{M}\right)$ (144). In vivo studies in diabetic rats treated with a polyphenolic fraction of $S$. miltiorrhiza, also evidenced a lower fasting glucose (145). In this way, the active ingredient tanshinone IIA reduced glycemia in fasted mice after an acute injection of a glucose bolus (146).

There is limited data from human assays exploring specific targeting PTP1B inhibitors, and that available investigated the effect of resveratrol. The first clinical trial, composed of a very small sample (total 19, 10 intervened and nine controls), found that $10 \mathrm{mg}$ /day of resveratrol capsule administered for a month improved HOMA-IR (91) meanwhile in other, performed in 28 medicated T2DM subjects treated with $250 \mathrm{mg} /$ day of resveratrol for 3 months improved HbAlc level (control $n=29$ ) (92). However, no effect of resveratrol was observed in three studies, in 15 post-menopausal women (control $\mathrm{n}=14$ ), 10 overweight men with no-alcoholic liver disease (control $n=14$ ) and 12 obese men (control $\mathrm{n}=12$ ) when was administrated in doses of $75 \mathrm{~g} /$ day for 12 weeks (93), 3,000 mg/day for 8 weeks (94) and $300 \mathrm{mg} /$ day for 4 weeks (95), respectively. In preliminary date from PREDIMED study (Prevention with Mediterranean Diet) 1,000 obese T2DM patients followed for two years improved FBG (96). Data of resveratrol clinical trials is resumed in Table 1. In general, the beneficial preventive or curative effect of resveratrol in T2DM depend on doses, time of intervention and characteristic of population, but as other phytochemicals, should be consumed as supplement, because the doses ingested through diet are very low. Moreover, urinary metabolites should be controlled (130, 147, 148).

\section{Estradiol Regulation Via 17 $\beta$ - Hydroxysteroid Dehydrogenase}

Estradiol induces metabolic homeostasis and its accumulation in serum may be indicative of estrogen resistance, metabolic deficiency and T2DM (149). In postmenopausal women, elevated levels of circulating estradiol were associated with T2DM (150) but did not reflected causality. 17 $\beta$-HSDs play a key role in both degradation and activation of androgens and estrogens. Specifically, 17 $\beta$-HSD1 facilitates the reduction of estrone to estradiol, while $17 \beta-\mathrm{HSD} 2$ mediates the oxidation of estradiol to estrone (151). In humans, $17 \beta$-HSD1 is expressed in placenta, ovary and breast epithelial cells, and 17 $\beta$-HSD2 in placenta, lung, liver, pancreas, kidney, prostate, colon, small intestine, endometrium and breast epithelial cells (151).

Stupans and Stretch (152) examined the ability of complex phenols from olive oil to inhibit human hepatic microsomal both reductive and oxidative $17 \beta$-HSD activity. Specifically, dihydroxybenzoic acid, gallic acid, hydroxytyrosol, and oleuropein glycoside inhibited the reductive $17 \beta$-HSD activity but not the oxidative one. Rather, gallic acid stimulated the activity by approximately $30 \%$ (152).

Some molecules, like epicatechin may also activate $17 \beta$-HSDs in rat testicular Leydig cells (153). In the same way, resveratrol also regulates protein and mRNA expression of $17 \beta-\mathrm{HSD}$ in rats $(154,155)$. Curcumin and quercetin increased the activity of $17 \beta$-HSD, but curcumin evidenced a slightly better activity as compared to quercetin (156). On the contrary, soy isoflavones treatment in female rats decreases 17 $\beta$-HSD levels (157). In this way, a previous report indicates that genistein can inhibit $17 \beta$-HSD enzyme in both human and rat testis microsomes (158).

There are few studies in human related to extra-virgin olive oil consume and T2DM (130). In two intervention studies, 500 $\mathrm{mg}$ of leaf extract improved insulin resistance parameters. The first study, performed in 21 overweight men treated for 12 weeks compared with 22 control men, improved $\beta$-cell function and insulin levels. Those parameters showed a higher improve when 36 subjects treated with hypolipemiant or anti-hypertensive medication were excluded (97). In another study, the intake of one capsule a day $(51.1 \mathrm{mg}$ oleuropein and $9.7 \mathrm{mg}$ hydroxytyrosol for 12 -week) improved pancreatic $\beta$-cell function and insulin sensitivity in T2DM patients. The other study was performed in 41 T2DM men for 14 week (control $n=$ 38) and showed an improvement of HbAlc and fasting insulin levels (98). The doses of olive leaf extract administrated had 51.1 mg oleuropein and $9.7 \mathrm{mg}$ hydroxytyrosol. In contrast, in other study, no significant effect was stated following administration of two polyphenol-rich olive oil ( $20 \mathrm{ml} /$ day, $6 \mathrm{mg}$ hydroxityrosol) for 6 weeks in 63 healthy participants (group $1 \mathrm{n}=39$, group 2 $n=29$, control $n=9$ ) (99). In yet another study performed in 11 overweight T2DM adults, found that the administration of $25 \mathrm{ml}$ of high phenol olive oil for 4 weeks reduced HbA1c and FBG (159). Finally, the PREDIMED trial revealed that Mediterranean diet supplemented with extra-virgin olive oil reduced in $40 \%$ the T2DM incidence while improved glucose metabolism in participants with high cardiovascular risk (100, 160). Also $50 \mathrm{ml}$ of virgin olive oil a day increased expression of insulinrelated candidate genes in peripheral mononuclear cells (161). Indeed, extra-virgin olive oil is not only rich in polyphenols, but also has flavonoids, flavones and lignans, that present action over glucose metabolism, that can be considered when data from intervention studies is analyzed.

\section{Incoming Glucose Into Hexosamine Biosynthesis Regulation via Glutamine- Fructose-6-Phosphate Aminotransferase}

Glutamine-fructose-6-phosphate aminotransferase (GFAT) is a rate-limiting enzyme in the hexosamine biosynthetic pathway that plays an important role in T2DM (162). GFAT enzyme converts fructose-6-phosphate to glucosamine-6-phosphate. In mammals, the glucose integration through the hexosamine biosynthetic pathway is regarded as a cell nutrient sensor and this pathway is one of the mechanisms through which hyperglycemia mediates peripheral insulin resistance (163) and diabetic complications (164). In this sense, an enhanced activity of human GFAT has been implicated in insulin resistance in cellular and animal models $(165,166)$.

In Wistar rats, fenugreek (Trigonella foenum-graecum L.) was revealed to be able to control the increase in GFAT activity provoked by corn starch diet and reduced kidney damage (167). Similarly, Coriandrum sativum L. fruit and its phytoconstituents evaluated in an evaluated in silico model (168), evidenced, specifically the compound limonene, to be a good inhibitor of GFAT. Indeed, a meta-analysis including 10 clinical trials revealed that fenugreek ingest between 1 and $100 \mathrm{~g} /$ day for 10 to 84 days reduced FBG by $-17.93 \mathrm{mg} / \mathrm{dl}, 2 \mathrm{~h}$ post-load glucose 
by $-39.46 \mathrm{mg} / \mathrm{dl}$ and $\mathrm{HbA} 1 \mathrm{c}$ by $-0.85 \%$. Fenugreek was administered in powder, alcoholic extract or capsules (169). More prominent changes were found in T2DM and overweight patients (20 case and 20 control subjects, $1 \mathrm{~g} /$ day for 2 weeks) $(102,169)$, and T2DM with coronary arterial disease (30 case and 30 control subjects, $25 \mathrm{~g} /$ twice daily for 1 week) $(101,103)$. It has been suggested that larger double blind randomized trials should be performed according to rigorous standards for herbal intervention, because the trails analyzed and available so far have low sample sizes ( $\leq 25$ subjects) (169). Another metaanalysis analyzing the same articles was performed later, with similar conclusions, highlighting therefore the low quality of studies and underlining the promising beneficial effects of fenugreek in pre-diabetes subjects (170). Another later simple study in 60 metformin-treated T2DM patients found that thrice daily $1 \mathrm{~g}$ fenugreek for 12 -week improved FBG, post-prandial glucose and HbA1c in higher proportion when compared to the group receiving only metformin ( $\mathrm{n}=30$ each group), suggesting that fenugreek can be used as complementary therapy in T2DM control (104). Meanwhile another longitudinal study found that in T2DM patient with hyperglycemia and under different treatments, $25 \mathrm{~g} /$ day of fenugreek for 24 week decreased glucosuria and HbA1c ( $\mathrm{n}=60,10$ control) (105).

\section{Insulin Secretion, Glucose Uptake and Gluconeogenesis Regulation via Mono- ADP-Ribosyltransferase-Sirtuin-6}

Sirtuin 6 (SIRT6) has both $\mathrm{NAD}^{+}$-dependent deacetylase (171) and mono-ADP-ribosyltransfease activity (172), and is targeted by antidiabetic epidrugs exhibiting inhibitory or activating mechanisms. Briefly, the absence of SIRT6 has been linked to an increased tissue glucose uptake and decreased serum glucose levels (173) through inhibiting the expression of the transcription factor hypoxia inducible factor (HIF)-1 $\alpha$, which is involved in the transcription of glucose transporters (174). Also, SIRT6 boosts the deacetylation of peroxisome proliferatoractivated receptor $-\gamma$ coactivator (PGC)- $1 \alpha$, which robustly stimulates hepatic gluconeogenesis (175).

The interactions between the main bioactive compounds of ginger (i.e., 4-gingerol, 6-gingerol, 8-gingerol, 10-gingerol, 6shogaol, and $\beta$-bisabolol) and protein targets (GFAT, SIRT6, GLUT4, 11 $\beta$-HSD1 and glycogen phosphorylase) were studied using computational interaction methods, molecular docking and pharmacophore (176). SIRT6 and GFAT showed binding affinity ranges lower than $11 \beta$-HSD1 and glycogen phosphorylase but more stables, and strong interaction with GLUT4 was observed. The study concluded that the synergistic mixture of ginger phytochemicals may have functional effects for T2DM treating therapy.

Euphorbia thymifolia L. is a medicinal plant with reported anti-hyperglycemic activity (177). In a study aiming to investigate the antidiabetic mechanism involved, molecular interactions between phytochemicals in E. thymifolia and protein targets (11 $\beta$-HSD1, GFAT, PTP1B, and SIRT6) were analyzed (178). As main findings, seven bioactive compounds with high binding affinity $(<-8.0 \mathrm{kcal} / \mathrm{mol})$ to all four targeted proteins were found, namely $\beta$-amyrine, taraxerol, 1-O-galloyl$\beta$-D-glucose, corilagin, cosmosiin, quercetin-3-galactoside and quercitrin. To date, there is no data available on clinical trials exploring specific targeting SIRT6 inhibitors, so that this should be an area of high search in the near future.

\section{CONCLUSION}

Epidrugs are another strategy to prevent or delay the T2DM onset through epigenetic mechanisms. The use of these new drugs has shown to have a high potential since they can genetically modulate diseases while other treatments act through other biochemical mechanisms. Many known plants (i.e. ginger, tea and fenugreek) and phytochemicals (i.e. curcumin and resveratrol) with an impact on diabetes have been shown to interact with different protein targets of T2DM. However, in some cases, there are controversial results. Data currently available underline that some bioactive compounds have epigenetic regulatory effects and appear to be useful for therapeutic and/or complementary purposes along with pharmacological hypoglycemic drugs, featured by numerous side effects. The mechanisms involved in the therapeutic effects of the potential epidrugs discussed in this review are the decrease of insulin resistance via 11ß-HSDs inhibition, the enhance of insulin activity via PTP1B inhibition, estradiol regulation via $17 \beta-\mathrm{HSD}$ inhibition, incoming glucose into hexosamine biosynthesis regulation via GFAT inhibition, and the role of SIRT6 in insulin secretion, glucose uptake and gluconeogenesis regulation. Further, increasingly deeper studies on natural and synthetic compounds and new protein targets must be performed. In addition, new preclinical studies must also be done to better elucidate the epigenetic mechanisms, along with new clinical studies to determine the effectiveness of these epidrugs.

\section{AUTHOR CONTRIBUTIONS}

AA-H, NC-M, JS-R, and MM, critically reviewed the manuscript. All authors contributed to the article and approved the submitted version.

\section{FUNDING}

This work was supported by CONICYT PIA/APOYO CCTE AFB170007.

\section{ACKNOWLEDGMENTS}

NC-M acknowledges the Portuguese Foundation for Science and Technology under the Horizon 2020 Program (PTDC/PSI-GER/ 28076/2017). 


\section{REFERENCES}

1. Zhou B, Lu Y, Hajifathalian K, Bentham J, Di Cesare M, Danaei G, et al. Worldwide Trends in Diabetes Since 1980: A Pooled Analysis of 751 Population-Based Studies With 4.4 Million Participants. Lancet (2016) 387(10027):1513-30. doi: 10.1016/S0140-6736(16)00618-8

2. Chatterjee S, Khunti K, Davies MJ. Type 2 Diabetes. Lancet (2017) 389 (10085):2239-51. doi: 10.1016/S0140-6736(17)30058-2

3. WHO. Diabetes. World Health Organization (Who) Report (2018). Available at: https://www.who.int/news-room/fact-sheets/detail/diabetes.

4. Haslam DW, James WPT. Obesity. Lancet (2005) 366(9492):1197-209. doi: 10.1016/S0140-6736(05)67483-1

5. Fradin D, Bougnères P. T2dm: Why Epigenetics? J Nutr Metab (2011) 2011:647514-. doi: 10.1155/2011/647514

6. Ling C. Epigenetic Regulation of Insulin Action and Secretion - Role in the Pathogenesis of Type 2 Diabetes. J Intern Med (2020) 288(2):158-67. doi: 10.1111/joim.13049

7. Shanak S, Saad B, Zaid H. Metabolic and Epigenetic Action Mechanisms of Antidiabetic Medicinal Plants. Evidence-Based Complement Altern Med (2019) 2019:18. doi: 10.1155/2019/3583067

8. Liu J, Lang G, Shi J. Epigenetic Regulation of PDX-1 in Type 2 Diabetes Mellitus. Diabetes Metab Syndr Obes (2021) 14:431-42. doi: 10.2147/ DMSO.S291932

9. Dayeh T, Volkov P, Salö S, Hall E, Nilsson E, Olsson AH, et al. GenomeWide DNA Methylation Analysis of Human Pancreatic Islets From Type 2 Diabetic and Non-Diabetic Donors Identifies Candidate Genes That Influence Insulin Secretion. PloS Genet (2014) 10(3):e1004160. doi: 10.1371/journal.pgen.1004160

10. Hall E, Dekker Nitert M, Volkov P, Malmgren S, Mulder H, Bacos K, et al. The Effects of High Glucose Exposure on Global Gene Expression and DNA Methylation in Human Pancreatic Islets. Mol Cell Endocrinol (2018) 472:5767. doi: 10.1016/j.mce.2017.11.019

11. Gancheva S, Ouni M, Jelenik T, Koliaki C, Szendroedi J, Toledo FGS, et al. Dynamic Changes of Muscle Insulin Sensitivity After Metabolic Surgery. Nat Commun (2019) 10(1):4179. doi: 10.1038/s41467-019-12081-0

12. Alkhalidy H, Wang Y, Liu D. Dietary Flavonoids in the Prevention of T2D: An Overview. Nutrients (2018) 10(4):1-33. doi: 10.3390/nu10040438

13. Ezuruike UF, Prieto JM. The Use of Plants in the Traditional Management of Diabetes in Nigeria: Pharmacological and Toxicological Considerations. J Ethnopharmacol (2014) 155(2):857-924. doi: 10.1016/j.jep.2014.05.055

14. Lee AL, Chen BC, Mou CH, Sun MF, Yen HR. Association of Traditional Chinese Medicine Therapy and the Risk of Vascular Complications in Patients With Type II Diabetes Mellitus: A Nationwide, Retrospective, Taiwanese-Registry, Cohort Study. Medicine (2016) 95(3):e2536. doi: 10.1097/MD.0000000000002536

15. Salehi B, Ata A, VAK N, Sharopov F, Ramírez-Alarcón K, Ruiz-Ortega A, et al. Antidiabetic Potential of Medicinal Plants and Their Active Components. Biomolecules (2019) 9(10):551. doi: 10.3390/biom9100551

16. Maruthur NM, Tseng E, Hutfless S, Wilson LM, Suarez-Cuervo C, Berger Z, et al. Diabetes Medications as Monotherapy or Metformin-Based Combination Therapy for Type 2 Diabetes: A Systematic Review and Meta-Analysis. Ann Internal Med (2016) 164(11):740-51. doi: 10.7326/ M15-2650

17. Mahomoodally MF, Mootoosamy A, Wambugu S. Traditional Therapies Used to Manage Diabetes and Related Complications in Mauritius: A Comparative Ethnoreligious Study. Evidence-Based Complement Altern Med eCAM (2016) 2016:4523828. doi: 10.1155/2016/4523828

18. Teoh SL, Das S. Phytochemicals and Their Effective Role in the Treatment of Diabetes Mellitus: A Short Review. Phytochem Rev (2018) 17(5):1111-28. doi: 10.1007/s11101-018-9575-Z

19. Ortega Á, Berná G, Rojas A, Martín F, Soria B. Gene-Diet Interactions in Type 2 Diabetes: The Chicken and Egg Debate. Int J Mol Sci (2017) 18 (6):1188. doi: 10.3390/ijms18061188

20. Kahn SE, Cooper ME, Del Prato S. Pathophysiology and Treatment of Type 2 Diabetes: Perspectives on the Past, Present, and Future. Lancet (2014) 383 (9922):1068-83. doi: 10.1016/S0140-6736(13)62154-6

21. Martinez-Moreno JM, Fontecha-Barriuso M, Martin-Sanchez D, GuerreroMauvecin J, Goma-Garces E, Fernandez-Fernandez B, et al. Epigenetic
Modifiers as Potential Therapeutic Targets in Diabetic Kidney Disease. Int J Mol Sci (2020) 21(11):4113. doi: 10.3390/ijms21114113

22. Ling C, Rönn T. Epigenetics in Human Obesity and Type 2 Diabetes. Cell Metab (2019) 29(5):1028-44. doi: 10.1016/j.cmet.2019.03.009

23. Allis CD, Jenuwein T. The Molecular Hallmarks of Epigenetic Control. Nat Rev Genet (2016) 17(8):487-500. doi: 10.1038/nrg.2016.59

24. Bonev B, Cavalli G. Organization and Function of the 3D Genome. Nat Rev Genet (2016) 17(11):661-78. doi: 10.1038/nrg.2016.112

25. Cavalli G, Heard E. Advances in Epigenetics Link Genetics to the Environment and Disease. Nature (2019) 571(7766):489-99. doi: 10.1038/ s41586-019-1411-0

26. You D, Nilsson E, Tenen DE, Lyubetskaya A, Lo JC, Jiang R, et al. Dnmt3a Is an Epigenetic Mediator of Adipose Insulin Resistance. Elife (2017) 6:1-20. doi: 10.7554/eLife.30766

27. Tan M, Luo H, Lee S, Jin F, Yang JS, Montellier E, et al. Identification of 67 Histone Marks and Histone Lysine Crotonylation as a New Type of Histone Modification. Cell (2011) 146(6):1016-28. doi: 10.1016/j.cell.2011.08.008

28. Alamdari N, Aversa Z, Castillero E, Hasselgren P-O. Acetylation and Deacetylation-Novel Factors in Muscle Wasting. Metabolism (2013) 62 (1):1-11. doi: 10.1016/j.metabol.2012.03.019

29. Hyun K, Jeon J, Park K, Kim J. Writing, Erasing and Reading Histone Lysine Methylations. Exp Mol Med (2017) 49(4):e324-e. doi: 10.1038/emm.2017.11

30. Martinez-Moreno JM, Fontecha-Barriuso M, Martín-Sánchez D, SánchezNiño MD, Ruiz-Ortega M, Sanz AB, et al. The Contribution of Histone Crotonylation to Tissue Health and Disease: Focus on Kidney Health. Front Pharmacol (2020) 11:393-. doi: 10.3389/fphar.2020.00393

31. Xie Z, Zhang D, Chung D, Tang Z, Huang H, Dai L, et al. Metabolic Regulation of Gene Expression by Histone Lysine $\beta$-Hydroxybutyrylation. Mol Cell (2016) 62(2):194-206. doi: 10.1016/j.molcel.2016.03.036

32. Kim M, Zhang X. The Profiling and Role of miRNAs in Diabetes Mellitus. J Diabetes Clin Res (2019) 1(1):5-23. doi: 10.33696/diabetes.1.003

33. Mongelli A, Martelli F, Farsetti A, Gaetano C. The Dark That Matters: Long Non-Coding Rnas as Master Regulators of Cellular Metabolism in NonCommunicable Diseases. Front Physiol (2019) 10:369. doi: 10.3389/ fphys.2019.00369

34. Hall E, Dayeh T, Kirkpatrick CL, Wollheim CB, Dekker Nitert M, Ling C. DNA Methylation of the Glucagon-Like Peptide 1 Receptor (GLP1R) in Human Pancreatic Islets. BMC Med Genet (2013) 14:76. doi: 10.1186/14712350-14-76

35. Yang BT, Dayeh TA, Volkov PA, Kirkpatrick CL, Malmgren S, Jing X, et al. Increased DNA Methylation and Decreased Expression of PDX-1 in Pancreatic Islets From Patients With Type 2 Diabetes. Mol Endocrinol (2012) 26(7):1203-12. doi: 10.1210/me.2012-1004

36. Prentki M, Nolan CJ. Islet Beta Cell Failure in Type 2 Diabetes. J Clin Invest (2006) 116(7):1802-12. doi: 10.1172/JCI29103

37. Avrahami D, Kaestner KH. The Dynamic Methylome of Islets in Health and Disease. Mol Metab (2019) 27S(Suppl):S25-32. doi: 10.1016/j.molmet. 2019.06.007

38. Ouni M, Saussenthaler S, Eichelmann F, Jähnert M, Stadion M, Wittenbecher C, et al. Epigenetic Changes in Islets of Langerhans Preceding the Onset of Diabetes. Diabetes (2020) 69(11):2503-17. doi: $10.2337 / \mathrm{db} 20-0204$

39. Wahl S, Drong A, Lehne B, Loh M, Scott WR, Kunze S, et al. EpigenomeWide Association Study of Body Mass Index, and the Adverse Outcomes of Adiposity. Nature (2017) 541(7635):81-6. doi: 10.1038/nature20784

40. Chambers JC, Loh M, Lehne B, Drong A, Kriebel J, Motta V, et al. Epigenome-Wide Association of DNA Methylation Markers in Peripheral Blood From Indian Asians and Europeans With Incident Type 2 Diabetes: A Nested Case-Control Study. Lancet Diabetes Endocrinol (2015) 3(7):526-34. doi: 10.1016/S2213-8587(15)00127-8

41. Liu ZH, Chen LL, Deng XL, Song HJ, Liao YF, Zeng TS, et al. Methylation Status of CpG Sites in the MCP-1 Promoter Is Correlated to Serum MCP-1 in Type 2 Diabetes. J Endocrinol Invest (2012) 35(6):585-9. doi: 10.3275/7981

42. Roshanzamir N, Hassan-Zadeh V. Methylation of Specific Cpg Sites in IL-1 $\beta$ and IL1R1 Genes Is Affected by Hyperglycaemia in Type 2 Diabetic Patients. Immunol Invest (2020) 49(3):287-98. doi: 10.1080/08820139.2019.1656227

43. Alhawiti NM, Al Mahri S, Aziz MA, Malik SS, Mohammad S. TXNIP in Metabolic Regulation: Physiological Role and Therapeutic Outlook. 
CurrDrug Targets (2017) 18(9):1095-103. doi: 10.2174/138945011 8666170130145514

44. Barrès R, Osler ME, Yan J, Rune A, Fritz T, Caidahl K, et al. Non-CpG Methylation of the PGC-1alpha Promoter Through DNMT3B Controls Mitochondrial Density. Cell Metab (2009) 10(3):189-98. doi: 10.1016/ j.cmet.2009.07.011

45. Miao F, Gonzalo IG, Lanting L, Natarajan R. In Vivo Chromatin Remodeling Events Leading to Inflammatory Gene Transcription Under Diabetic Conditions. J Biol Chem (2004) 279(17):18091-7. doi: 10.1074/ jbc.M311786200

46. Pirola L, Balcerczyk A, Tothill RW, Haviv I, Kaspi A, Lunke S, et al. Genome-Wide Analysis Distinguishes Hyperglycemia Regulated Epigenetic Signatures of Primary Vascular Cells. Genome Res (2011) 21 (10):1601-15. doi: 10.1101/gr.116095.110

47. Ibarra Urizar A, Prause M, Wortham M, Sui Y, Thams P, Sander M, et al. Beta-Cell Dysfunction Induced by Non-Cytotoxic Concentrations of Interleukin-1 $\beta$ Is Associated With Changes in Expression of Beta-Cell Maturity Genes and Associated Histone Modifications. Mol Cell Endocrinol (2019) 496:110524. doi: 10.1016/j.mce.2019.110524

48. El-Osta A, Brasacchio D, Yao D, Pocai A, Jones PL, Roeder RG, et al. Transient High Glucose Causes Persistent Epigenetic Changes and Altered Gene Expression During Subsequent Normoglycemia. J Exp Med (2008) 205 (10):2409-17. doi: 10.1084/jem.20081188

49. Paneni F, Costantino S, Battista R, Castello L, Capretti G, Chiandotto S, et al. Adverse Epigenetic Signatures by Histone Methyltransferase Set7 Contribute to Vascular Dysfunction in Patients With Type 2 Diabetes Mellitus. Circ Cardiovasc Genet (2015) 8(1):150-8. doi: 10.1161/CIRCGENETICS. 114.000671

50. Okabe J, Orlowski C, Balcerczyk A, Tikellis C, Thomas MC, Cooper ME, et al. Distinguishing Hyperglycemic Changes by Set7 in Vascular Endothelial Cells. Circ Res (2012) 110(8):1067-76. doi: 10.1161/ CIRCRESAHA.112.266171

51. Huang B, Yang XD, Zhou MM, Ozato K, Chen LF. Brd4 Coactivates Transcriptional Activation of NF-kappaB Via Specific Binding to Acetylated Rela. Mol Cell Biol (2009) 29(5):1375-87. doi: 10.1128/ MCB.01365-08

52. Akbari M, Hassan-Zadeh V. The Inflammatory Effect of Epigenetic Factors and Modifications in Type 2 Diabetes. Inflammopharmacology (2020) 28 (2):345-62. doi: 10.1007/s10787-019-00663-9

53. Villeneuve LM, Kato M, Reddy MA, Wang M, Lanting L, Natarajan R. Enhanced Levels of microRNA-125b in Vascular Smooth Muscle Cells of Diabetic Db/Db Mice Lead to Increased Inflammatory Gene Expression by Targeting the Histone Methyltransferase Suv39h1. Diabetes (2010) 59 (11):2904-15. doi: 10.2337/db10-0208

54. Smith KM, Guerau-de-Arellano M, Costinean S, Williams JL, Bottoni A, Mavrikis Cox G, et al. miR-29ab1 Deficiency Identifies a Negative Feedback Loop Controlling Th1 Bias That Is Dysregulated in Multiple Sclerosis. J Immunol (2012) 189(4):1567-76. doi: 10.4049/jimmunol.1103171

55. Reddy MA, Chen Z, Park JT, Wang M, Lanting L, Zhang Q, et al. Regulation of Inflammatory Phenotype in Macrophages by a Diabetes-Induced Long Noncoding RNA. Diabetes (2014) 63(12):4249-61. doi: 10.2337/db14-0298

56. Sathishkumar C, Prabu P, Mohan V, Balasubramanyam M. Linking a Role of IncRNAs (Long non-Coding RNAs) With Insulin Resistance, Accelerated Senescence, and Inflammation in Patients With Type 2 Diabetes. Hum Genomics (2018) 12(1):41-. doi: 10.1186/s40246-018-0173-3

57. Jayasinghe CD, Udalamaththa A, Imbulana IBPS, Suetake I. Dietary Phytochemicals as Epi-Drugs: Role in Modulating the Epigenetic Mechanisms of Human Diseases. Int J Curr Pharm Rev Res (2016) 7:50-8. doi: 10.1186/s13287-016-0366-4

58. Shukla S, Penta D, Mondal P, Meeran SM. Epigenetics of Breast Cancer: Clinical Status of Epi-Drugs and Phytochemicals. Adv Exp Med Biol (2019) 1152:293-310. doi: 10.1007/978-3-030-20301-6_16

59. Proshkina E, Shaposhnikov M, Moskalev A. Genome-Protecting Compounds as Potential Geroprotectors. Int J Mol Sci (2020) 21(12):4484. doi: $10.3390 /$ ijms 21124484

60. Arablou T, Aryaeian N, Valizadeh M, Sharifi F, Hosseini A, Djalali M. The Effect of Ginger Consumption on Glycemic Status, Lipid Profile and Some Inflammatory Markers in Patients With Type 2 Diabetes
Mellitus. Int J Food Sci Nutr (2014) 65(4):515-20. doi: 10.3109/ 09637486.2014.880671

61. Mahluji S, Attari VE, Mobasseri M, Payahoo L, Ostadrahimi A, Golzari SE. Effects of Ginger (Zingiber Officinale) on Plasma Glucose Level, HbAlc and Insulin Sensitivity in Type 2 Diabetic Patients. Int J Food Sci Nutr (2013) 64 (6):682-6. doi: 10.3109/09637486.2013.775223

62. Mozaffari-Khosravi H, Talaei B, Jalali BA, Najarzadeh A, Mozayan MR. The Effect of Ginger Powder Supplementation on Insulin Resistance and Glycemic Indices in Patients With Type 2 Diabetes: A Randomized, Double-Blind, Placebo-Controlled Trial. Complement Ther Med (2014) 22 (1):9-16. doi: 10.1016/j.ctim.2013.12.017

63. Shidfar F, Rajab A, Rahideh T, Khandouzi N, Hosseini S, Shidfar S. The Effect of Ginger (Zingiber Officinale) on Glycemic Markers in Patients With Type 2 Diabetes. J Complement Integr Med (2015) 12(2):165-70. doi: 10.1515/jcim-2014-0021

64. Attari VE, Mahluji S, Asghari Jafarabadi M, Ostadrahimi A. Effects of Supplementation With Ginger (Zingiber Officinale Roscoe) on Serum Glucose, Lipid Profile and Oxidative Stress in Obese Women: A Randomized, Placebo-Controlled Clinical Trial. Pharm Sci (2015) 21 (4):184-91. doi: 10.15171/PS.2015.35

65. Attari VE, Ostadrahimi A, Asghari Jafarabadi M, Mehralizadeh S, Mahluji S. Changes of Serum Adipocytokines and Body Weight Following Zingiber Officinale Supplementation in Obese Women: A RCT. Eur J Nutr (2016) 55 (6):2129-36. doi: 10.1007/s00394-015-1027-6

66. Imani H, Tabibi H, Najafi I, Atabak S, Hedayati M, Rahmani L. Effects of Ginger on Serum Glucose, Advanced Glycation End Products, and Inflammation in Peritoneal Dialysis Patients. Nutrition (2015) 31(5):7037. doi: 10.1016/j.nut.2014.11.020

67. Yang G, Shu XO, Jin F, Elasy T, Li HL, Li Q, et al. Soyfood Consumption and Risk of Glycosuria: A Cross-Sectional Study Within the Shanghai Women's Health Study. Eur J Clin Nutr (2004) 58(4):615-20. doi: 10.1038/ sj.ejcn. 1601855

68. Usui T, Tochiya M, Sasaki Y, Muranaka K, Yamakage H, Himeno A, et al. Effects of Natural S-equol Supplements on Overweight or Obesity and Metabolic Syndrome in the Japanese, Based on Sex and Equol Status. Clin Endocrinol (Oxf) (2013) 78(3):365-72. doi: 10.1111/j.1365-2265. 2012.04400.x

69. Atteritano M, Marini H, Minutoli L, Polito F, Bitto A, Altavilla D, et al. Effects of the Phytoestrogen Genistein on Some Predictors of Cardiovascular Risk in Osteopenic, Postmenopausal Women: A Two-Year Randomized, Double-Blind, Placebo-Controlled Study. J Clin Endocrinol Metab (2007) 92 (8):3068-75. doi: 10.1210/jc.2006-2295

70. Pan A, Sun J, Chen Y, Ye X, Li H, Yu Z, et al. Effects of a Flaxseed-Derived Lignan Supplement in Type 2 Diabetic Patients: A Randomized, DoubleBlind, Cross-Over Trial. PloS One (2007) 2(11):e1148-e. doi: 10.1371/ journal.pone. 0001148

71. Ho SC, Chen Y-m, Ho SSS, Woo JLF. Soy Isoflavone Supplementation and Fasting Serum Glucose and Lipid Profile Among Postmenopausal Chinese Women: A Double-Blind, Randomized, Placebo-Controlled Trial. Menopause (2007) 14(5):905-12. doi: 10.1097/gme.0b013e318032b2d3

72. van der Schouw YT, Sampson L, Willett WC, Rimm EB. The Usual Intake of Lignans But Not That of Isoflavones may be Related to Cardiovascular Risk Factors in U. S Men J Nutr (2005) 135(2):260-6. doi: 10.1093/jn/ 135.2.260

73. Mueller NT, Odegaard AO, Gross MD, Koh WP, Yu MC, Yuan JM, et al. Soy Intake and Risk of Type 2 Diabetes in Chinese Singaporeans [Corrected]. Eur J Nutr (2012) 51(8):1033-40. doi: 10.1007/s00394-011-0276-2

74. Villegas R, Gao YT, Yang G, Li HL, Elasy TA, Zheng W, et al. Legume and Soy Food Intake and the Incidence of Type 2 Diabetes in the Shanghai Women's Health Study. Am J Clin Nutr (2008) 87(1):162-7. doi: 10.1093/ ajcn/87.1.162

75. Morimoto Y, Steinbrecher A, Kolonel LN, Maskarinec G. Soy Consumption Is Not Protective Against Diabetes in Hawaii: The Multiethnic Cohort. Eur J Clin Nutr (2011) 65(2):279-82. doi: 10.1038/ejcn.2010.228

76. Nanri A, Mizoue T, Takahashi Y, Kirii K, Inoue M, Noda M, et al. Soy Product and Isoflavone Intakes Are Associated With a Lower Risk of Type 2 Diabetes in Overweight Japanese Women. J Nutr (2010) 140(3):580-6. doi: 10.3945/jn.109.116020 
77. Zamora-Ros R, Forouhi NG, Sharp SJ, González CA, Buijsse B, Guevara M, et al. The Association Between Dietary Flavonoid and Lignan Intakes and Incident Type 2 Diabetes in European Populations: The EPIC-InterAct Study. Diabetes Care (2013) 36(12):3961-70. doi: 10.2337/dc13-0877

78. Shi L, Ryan HH, Jones E, Simas TAM, Lichtenstein AH, Sun Q, et al. Urinary Isoflavone Concentrations Are Inversely Associated With Cardiometabolic Risk Markers in Pregnant U. S Women J Nutr (2014) 144(3):344-51. doi: 10.3945/jn.113.184069

79. Goodman-Gruen D, Kritz-Silverstein D. Usual Dietary Isoflavone Intake Is Associated With Cardiovascular Disease Risk Factors in Postmenopausal Women. J Nutr (2001) 131(4):1202-6. doi: 10.1093/jn/131.4.1202

80. Sun Q, Wedick NM, Pan A, Townsend MK, Cassidy A, Franke AA, et al. Gut Microbiota Metabolites of Dietary Lignans and Risk of Type 2 Diabetes: A Prospective Investigation in Two Cohorts of U. S Women Diabetes Care (2014) 37(5):1287-95. doi: 10.2337/dc13-2513

81. Rahimi HR, Mohammadpour AH, Dastani M, Jaafari MR, Abnous K, Ghayour Mobarhan M, et al. The Effect of Nano-Curcumin on HbAlc, Fasting Blood Glucose, and Lipid Profile in Diabetic Subjects: A Randomized Clinical Trial. Avicenna J Phytomed (2016) 6(5):567-77.

82. Chuengsamarn S, Rattanamongkolgul S, Luechapudiporn R, Phisalaphong C, Jirawatnotai S. Curcumin Extract for Prevention of Type 2 Diabetes. Diabetes Care (2012) 35(11):2121-7. doi: 10.2337/dc12-0116

83. Panahi Y, Khalili N, Sahebi E, Namazi S, Simental-Mendía LE, Majeed M, et al. Effects of Curcuminoids Plus Piperine on Glycemic, Hepatic and Inflammatory Biomarkers in Patients With Type 2 Diabetes Mellitus: A Randomized Double-Blind Placebo-Controlled Trial. Drug Res (Stuttg) (2018) 68(7):403-9. doi: 10.1055/s-0044-101752

84. Na LX, Li Y, Pan HZ, Zhou XL, Sun DJ, Meng M, et al. Curcuminoids Exert Glucose-Lowering Effect in Type 2 Diabetes by Decreasing Serum Free Fatty Acids: A Double-Blind, Placebo-Controlled Trial. Mol Nutr Food Res (2013) 57(9):1569-77. doi: 10.1002/mnfr.201200131

85. Toolsee NA, Aruoma OI, Gunness TK, Kowlessur S, Dambala V, Murad F, et al. Effectiveness of Green Tea in a Randomized Human Cohort: Relevance to Diabetes and Its Complications. BioMed Res Int (2013) 2013:412379-. doi: $10.1155 / 2013 / 412379$

86. Alves Ferreira M, Oliveira Gomes AP, Guimarães de Moraes AP, Ferreira Stringhini ML, Mota JF, Siqueira Guedes Coelho A, et al. Green Tea Extract Outperforms Metformin in Lipid Profile and Glycaemic Control in Overweight Women: A Double-Blind, PlaceboControlled, Randomized Trial. Clin Nutr ESPEN (2017) 22:1-6. doi: 10.1016/j.clnesp.2017.08.008

87. Lasaite L, Spadiene A, Savickiene N, Skesters A, Silova A. The Effect of Ginkgo Biloba and Camellia Sinensis Extracts on Psychological State and Glycemic Control in Patients With Type 2 Diabetes Mellitus. Nat Prod Commun (2014) 9(9):1345-50. doi: 10.1177/1934578X1400900931

88. Mahmoud F, Al-Ozairi E, Haines D, Novotny L, Dashti A, Ibrahim B, et al. Effect of Diabetea Tea ${ }^{\text {TM }}$ Consumption on Inflammatory Cytokines and Metabolic Biomarkers in Type 2 Diabetes Patients. J Ethnopharmacol (2016) 194:1069-77. doi: 10.1016/j.jep.2016.10.073

89. Vaz SR, de Amorim LMN, de Nascimento PVF, Veloso VSP, Nogueira MS, Castro IA, et al. Effects of Green Tea Extract on Oxidative Stress and Renal Function in Diabetic Individuals: A Randomized, Double-Blinded, Controlled Trial. J Funct Foods (2018) 46:195-201. doi: 10.1016/ j.jff.2018.04.059

90. Hadi S, Alipour M, Aghamohammadi V, Shahemi S, Ghafouri-Taleghani F, Pourjavidi N, et al. Improvement in Fasting Blood Sugar, Anthropometric Measurement and hs-CRP After Consumption of epigallocatechin-3-gallate (EGCG) in Patients With Type 2 Diabetes Mellitus. Nutr Food Sci (2019) 50 (2):348-59. doi: 10.1108/NFS-04-2019-0126

91. Brasnyó P, Molnár GA, Mohás M, Markó L, Laczy B, Cseh J, et al. Resveratrol Improves Insulin Sensitivity, Reduces Oxidative Stress and Activates the Akt Pathway in Type 2 Diabetic Patients. Br J Nutr (2011) 106(3):383-9. doi: 10.1017/S0007114511000316

92. Bhatt JK, Thomas S, Nanjan MJ. Resveratrol Supplementation Improves Glycemic Control in Type 2 Diabetes Mellitus. Nutr Res (2012) 32(7):53741. doi: 10.1016/j.nutres.2012.06.003

93. Yoshino J, Conte C, Fontana L, Mittendorfer B, Imai S, Schechtman KB, et al. Resveratrol Supplementation Does Not Improve Metabolic Function in
Nonobese Women With Normal Glucose Tolerance. Cell Metab (2012) 16 (5):658-64. doi: 10.1016/j.cmet.2012.09.015

94. Chachay VS, Macdonald GA, Martin JH, Whitehead JP, O’Moore-Sullivan TM, Lee P, et al. Resveratrol Does Not Benefit Patients With Nonalcoholic Fatty Liver Disease. Clin Gastroenterol Hepatol (2014) 12(12):2092-103.e16. doi: 10.1016/j.cgh.2014.02.024

95. Poulsen MM, Vestergaard PF, Clasen BF, Radko Y, Christensen LP, Stødkilde-Jørgensen $\mathrm{H}$, et al. High-Dose Resveratrol Supplementation in Obese Men: An Investigator-Initiated, Randomized, Placebo-Controlled Clinical Trial of Substrate Metabolism, Insulin Sensitivity, and Body Composition. Diabetes (2013) 62(4):1186-95. doi: 10.2337/ db12-0975

96. Zamora-Ros R, Urpi-Sarda M, Lamuela-Raventós RM, Martínez-González M, Salas-Salvadó J, Arós F, et al. High Urinary Levels of Resveratrol Metabolites Are Associated With a Reduction in the Prevalence of Cardiovascular Risk Factors in High-Risk Patients. Pharmacol Res (2012) 65(6):615-20. doi: 10.1016/j.phrs.2012.03.009

97. de Bock M, Derraik JG, Brennan CM, Biggs JB, Morgan PE, Hodgkinson SC, et al. Olive (Olea Europaea L.) Leaf Polyphenols Improve Insulin Sensitivity in Middle-Aged Overweight Men: A Randomized, Placebo-Controlled, Crossover Trial. Plos One (2013) 8(3):e57622. doi: 10.1371/ journal.pone.0057622

98. Wainstein J, Ganz T, Boaz M, Bar Dayan Y, Dolev E, Kerem Z, et al. Olive Leaf Extract as a Hypoglycemic Agent in Both Human Diabetic Subjects and in Rats. J Med Food (2012) 15(7):605-10. doi: 10.1089/jmf.2011.0243

99. Silva S, Bronze MR, Figueira ME, Siwy J, Mischak H, Combet E, et al. Impact of a 6-Wk Olive Oil Supplementation in Healthy Adults on Urinary Proteomic Biomarkers of Coronary Artery Disease, Chronic Kidney Disease, and Diabetes (Types 1 and 2): A Randomized, Parallel, Controlled, Double-Blind Study. Am J Clin Nutr (2015) 101(1):44-54. doi: 10.3945/ajcn.114.094219

100. Salas-Salvadó J, Bulló M, Estruch R, Ros E, Covas MI, Ibarrola-Jurado N, et al. Prevention of Diabetes With Mediterranean Diets: A Subgroup Analysis of a Randomized Trial. Ann Internal Med (2014) 160(1):1-10. doi: 10.7326/M13-1725

101. Bordia A, Verma SK, Srivastava KC. Effect of Ginger (Zingiber Officinale Rosc.) and Fenugreek (Trigonella Foenumgraecum L.) on Blood Lipids, Blood Sugar and Platelet Aggregation in Patients With Coronary Artery Disease. Prostaglandins Leukot Essent Fatty Acids (1997) 56(5):379-84. doi: 10.1016/S0952-3278(97)90587-1

102. Chevassus H, Gaillard JB, Farret A, Costa F, Gabillaud I, Mas E, et al. A Fenugreek Seed Extract Selectively Reduces Spontaneous Fat Intake in Overweight Subjects. Eur J Clin Pharmacol (2010) 66(5):449-55. doi: 10.1007/s00228-009-0770-0

103. Lu FR, Shen L, Qin Y, Gao L, Li H, Dai Y. Clinical Observation on Trigonella Foenum-Graecum L. Total Saponins in Combination With Sulfonylureas in the Treatment of Type 2 Diabetes Mellitus. Chin J Integr Med (2008) 14 (1):56-60. doi: 10.1007/s11655-007-9005-3

104. Kaur M, Singh N, Sharma G, Singh D. To Study the Efficacy and Tolerability of Fenugreek Seed Powder as Add-on Therapy With Metformin in Patients of Type-2 Diabetes Mellitus. Int J Basic Clin Pharmacol (2016) 5(2):378-83. doi: 10.18203/2319-2003.ijbcp20160748

105. Sharma RD, Sarkar A, Hazara DK, Mishra B, Singh JB, Sharma SK, et al. Use of Fenuqreek Seed Powder in the Management of non-Insulin Dependent Diabetes Mellitus. Nutr Res (1996) 16(8):1331-9. doi: 10.1016/0271-5317(96) 00141-8

106. Zinker B, Mika A, Nguyen P, Wilcox D, Ohman L, von Geldern TW, et al. Liver-Selective Glucocorticoid Receptor Antagonism Decreases Glucose Production and Increases Glucose Disposal, Ameliorating Insulin Resistance. Metabolism-Clin Exp (2007) 56(3):380-7. doi: 10.1016/ j.metabol.2006.10.021

107. Pereira CD, Azevedo I, Monteiro R, Martins MJ. 11beta-Hydroxysteroid Dehydrogenase Type 1: Relevance of Its Modulation in the Pathophysiology of Obesity, the Metabolic Syndrome and Type 2 Diabetes Mellitus. Diabetes Obes Metab (2012) 14(10):869-81. doi: 10.1111/j.1463-1326.2012.01582.x

108. Cabrera Pérez LC, Padilla M II, Cruz A, Correa Basurto J, Miliar García Á, Hernández Zavala AA, et al. Design, Synthesis, Molecular Docking and In Vitro Evaluation of Benzothiazole Derivatives as $11 \beta$-Hydroxysteroid 
Dehydrogenase Type 1 Inhibitors. Mol Divers (2020) 24(4):1-14. doi: 10.1007/s11030-019-10006-z

109. Bailey MA. 11beta-Hydroxysteroid Dehydrogenases and Hypertension in the Metabolic Syndrome. Curr Hypertension Rep (2017) 19(12):100. doi: 10.1007/s11906-017-0797-z

110. Morton NM. Obesity and Corticosteroids: 11 beta-Hydroxysteroid Type 1 as a Cause and Therapeutic Target in Metabolic Disease. Mol Cell Endocrinol (2010) 316(2):154-64. doi: 10.1016/j.mce.2009.09.024

111. Zhu Q, Ge F, Dong Y, Sun W, Wang Z, Shan Y, et al. Comparison of Flavonoids and Isoflavonoids to Inhibit Rat and Human $11 \beta$-Hydroxysteroid Dehydrogenase 1 and 2. Steroids (2018) 132:25-32. doi: 10.1016/ j.steroids.2018.01.013

112. Torres-Piedra M, Ortiz-Andrade R, Villalobos-Molina R, Singh N, MedinaFranco JL, Webster SP, et al. A Comparative Study of Flavonoid Analogues on Streptozotocin-Nicotinamide Induced Diabetic Rats: Quercetin as a Potential Antidiabetic Agent Acting Via 11beta-Hydroxysteroid Dehydrogenase Type 1 Inhibition. Eur J Med Chem (2010) 45(6):2606-12. doi: 10.1016/j.ejmech.2010.02.049

113. Tagawa N, Kubota S, Kobayashi Y, Kato I. Genistein Inhibits Glucocorticoid Amplification in Adipose Tissue by Suppression of 11beta-Hydroxysteroid Dehydrogenase Type 1. Steroids (2015) 93:77-86. doi: 10.1016/ j.steroids.2014.11.003

114. Rockwood S, Broderick TL, Al-Nakkash L. Feeding Obese Diabetic Mice a Genistein Diet Induces Thermogenic and Metabolic Change. J Med Food (2018) 21(4):332-9. doi: 10.1089/jmf.2017.0084

115. Teich T, Pivovarov JA, Porras DP, Dunford EC, Riddell MC. Curcumin Limits Weight Gain, Adipose Tissue Growth, and Glucose Intolerance Following the Cessation of Exercise and Caloric Restriction in Rats. J Appl Physiol (Bethesda Md 1985) (2017) 123(6):1625-34. doi: 10.1152/ japplphysiol.01115.2016

116. Hu GX, Lin H, Lian QQ, Zhou SH, Guo J, Zhou HY, et al. Curcumin as a Potent and Selective Inhibitor of 11beta-Hydroxysteroid Dehydrogenase 1: Improving Lipid Profiles in High-Fat-Diet-Treated Rats. PloS One (2013) 8 (3):e49976. doi: 10.1371/journal.pone.0049976

117. Tagawa N, Kubota S, Kato I, Kobayashi Y. Resveratrol Inhibits 11betaHydroxysteroid Dehydrogenase Type 1 Activity in Rat Adipose Microsomes. J Endocrinol (2013) 218(3):311-20. doi: 10.1530/JOE-13-0066

118. Hintzpeter J, Stapelfeld C, Loerz C, Martin HJ, Maser E. Green Tea and One of Its Constituents, Epigallocatechine-3-gallate, Are Potent Inhibitors of Human 11beta-Hydroxysteroid Dehydrogenase Type 1. PloS One (2014) 9 (1):e84468. doi: 10.1371/journal.pone.0084468

119. Zhu J, Chen H, Song Z, Wang X, Sun Z. Effects of Ginger (Zingiber Officinale Roscoe) on Type 2 Diabetes Mellitus and Components of the Metabolic Syndrome: A Systematic Review and Meta-Analysis of Randomized Controlled Trials. Evidence-Based Complement Altern Med eCAM (2018) 2018:5692962. doi: 10.1155/2018/5692962

120. Feng T, Su J, Ding Z-H, Zheng Y-T, Li Y, Leng Y, et al. Chemical Constituents and Their Bioactivities of "Tongling White Ginger" (Zingiber Officinale). J Agric Food Chem (2011) 59(21):11690-5. doi: 10.1021/ if $202544 \mathrm{w}$

121. Whorwood CB, Sheppard MC, Stewart PM. Licorice Inhibits 11 BetaHydroxysteroid Dehydrogenase Messenger Ribonucleic Acid Levels and Potentiates Glucocorticoid Hormone Action. Endocrinology (1993) 132 (6):2287-92. doi: 10.1210/endo.132.6.8504732

122. Gumy C, Thurnbichler C, Aubry EM, Balazs Z, Pfisterer P, Baumgartner L, et al. Inhibition of 11 Beta-Hydroxysteroid Dehydrogenase Type 1 by Plant Extracts Used as Traditional Antidiabetic Medicines. Fitoterapia (2009) 80 (3):200-5. doi: 10.1016/j.fitote.2009.01.009

123. Talaei M, Pan A. Role of Phytoestrogens in Prevention and Management of Type 2 Diabetes. World J Diabetes (2015) 6(2):271-83. doi: 10.4239/ wjd.v6.i2.271

124. Pivari F, Mingione A, Brasacchio C, Soldati L. Curcumin and Type 2 Diabetes Mellitus: Prevention and Treatment. Nutrients (2019) 11(8):1837. doi: $10.3390 /$ nu1 1081837

125. Rivera-Mancía S, Trujillo J, Chaverri JP. Utility of Curcumin for the Treatment of Diabetes Mellitus: Evidence From Preclinical and Clinical Studies. J Nutr Intermediary Metab (2018) 14:29-41. doi: 10.1016/ j.jnim.2018.05.001
126. Cione E, La Torre C, Cannataro R, Caroleo MC, Plastina P, Gallelli L. Quercetin, Epigallocatechin Gallate, Curcumin, and Resveratrol: From Dietary Sources to Human MicroRNA Modulation. Molecules (2019) 25 (1):1-26. doi: 10.3390/molecules25010063

127. Sanchez M, Gonzalez-Burgos E, Iglesias I, Lozano R, Gomez-Serranillos MP. The Pharmacological Activity of Camellia Sinensis (L.) Kuntze on Metabolic and Endocrine Disorders: A Systematic Review. Biomolecules (2020) 10(4):127. doi: 10.3390/biom 10040603

128. Rafieian-Kopaei M, Motamedi P, Vakili L, Dehghani N, Kiani F, Taheri Z, et al. Green Tea and Type 2 Diabetes Mellitus. J Nephropharmacol (2014) 3 (1):21-3. doi: 10.1016/j.imr.2013.12.002

129. Mousavi A, Vafa M, Neyestani T, Khamseh M, Hoseini F. The Effects of Green Tea Consumption on Metabolic and Anthropometric Indices in Patients With Type 2 Diabetes. J Res Med Sci (2013) 18(12):1080-6.

130. Guasch-Ferré M, Merino J, Sun Q, Fitó M, Salas-Salvadó J. Dietary Polyphenols, Mediterranean Diet, Prediabetes, and Type 2 Diabetes: A Narrative Review of the Evidence. Oxid Med Cell Longev (2017) 2017:6723931. doi: 10.1155/2017/6723931

131. Hussain H, Green IR, Abbas G, Adekenov SM, Hussain W, Ali I. Protein Tyrosine Phosphatase 1B (PTP1B) Inhibitors as Potential Anti-Diabetes Agents: Patent Review (2015-2018). Expert Opin Ther Patents (2019) 29 (9):1-14. doi: 10.1080/13543776.2019.1655542

132. Zheng WH, Kar S, Quirion R. Insulin-Like Growth factor-1-Induced Phosphorylation of Transcription Factor FKHRL1 Is Mediated by Phosphatidylinositol 3-Kinase/Akt Kinase and Role of This Pathway in Insulin-Like Growth factor-1-Induced Survival of Cultured Hippocampal Neurons. Mol Pharmacol (2002) 62(2):225-33. doi: 10.1124/mol.62.2.225

133. Jiang CS, Liang LF, Guo YW. Natural Products Possessing Protein Tyrosine Phosphatase 1B (PTP1B) Inhibitory Activity Found in the Last Decades. Acta Pharmacol Sin (2012) 33(10):1217-45. doi: 10.1038/aps.2012.90

134. Gonzalez-Rodriguez A, Santamaria B, Mas-Gutierrez JA, Rada P, FernandezMillan E, Pardo V, et al. Resveratrol Treatment Restores Peripheral Insulin Sensitivity in Diabetic Mice in a sirt1-Independent Manner. Mol Nutr Food Res (2015) 59(8):1431-42. doi: 10.1002/mnfr.201400933

135. Rodgers JT, Lerin C, Haas W, Gygi SP, Spiegelman BM, Puigserver P. Nutrient Control of Glucose Homeostasis Through a Complex of PGClalpha and SIRT1. Nature (2005) 434(7029):113-8. doi: 10.1038/ nature 03354

136. Sun C, Zhang F, Ge X, Yan T, Chen X, Shi X, et al. SIRT1 Improves Insulin Sensitivity Under Insulin-Resistant Conditions by Repressing PTP1B. Cell Metab (2007) 6(4):307-19. doi: 10.1016/j.cmet.2007.08.014

137. Li X, Lee YJ, Jin F, Park YN, Deng Y, Kang Y, et al. Sirt1 Negatively Regulates FcepsilonRI-mediated Mast Cell Activation Through AMPK- and PTP1Bdependent Processes. Sci Rep (2017) 7(1):6444. doi: 10.1038/s41598-01706835-3

138. Chuang CC, Martinez K, Xie G, Kennedy A, Bumrungpert A, Overman A, et al. Quercetin Is Equally or More Effective Than Resveratrol in Attenuating Tumor Necrosis Factor-\{Alpha\}-Mediated Inflammation and Insulin Resistance in Primary Human Adipocytes. Am J Clin Nutr (2010) 92 (6):1511-21. doi: 10.3945/ajcn.2010.29807

139. Kostrzewa T, Przychodzen P, Gorska-Ponikowska M, Kuban-Jankowska A. Curcumin and Cinnamaldehyde as PTP1B Inhibitors With Antidiabetic and Anticancer Potential. Anticancer Res (2019) 39(2):745-9. doi: 10.21873/ anticanres. 13171

140. Li JM, Li YC, Kong LD, Hu QH. Curcumin Inhibits Hepatic ProteinTyrosine Phosphatase 1B and Prevents Hypertriglyceridemia and Hepatic Steatosis in Fructose-Fed Rats. Hepatol (Baltimore Md) (2010) 51(5):155566. doi: 10.1002/hep.23524

141. Ding XQ, Gu TT, Wang W, Song L, Chen TY, Xue QC, et al. Curcumin Protects Against Fructose-Induced Podocyte Insulin Signaling Impairment Through Upregulation of Mir-206. Mol Nutr Food Res (2015) 59(12):235570. doi: $10.1002 / \mathrm{mnfr} .201500370$

142. Bustanji Y, Taha MO, Al-Masri IM, Mohammad MK. Docking Simulations and In Vitro Assay Unveil Potent Inhibitory Action of Papaverine Against Protein Tyrosine Phosphatase 1B. Biol Pharm Bull (2009) 32(4):640-5. doi: $10.1248 / \mathrm{bpb} .32 .640$

143. Xu F, Wang F, Wang Z, Lv W, Wang W, Wang Y. Glucose Uptake Activities of Bis (2, 3-Dibromo-4, 5-Dihydroxybenzyl) Ether, a Novel Marine Natural 
Product From Red Alga Odonthaliacorymbifera With Protein Tyrosine Phosphatase 1b Inhibition, in Vitro and In Vivo. PloS One (2016) 11(1): e0147748-e. doi: 10.1371/journal.pone.0147748

144. Kim DH, Paudel P, Yu T, Ngo TM, Kim JA, Jung HA, et al. Characterization of the Inhibitory Activity of Natural Tanshinones From Salvia Miltiorrhiza Roots on Protein Tyrosine Phosphatase 1B. Chemico-biol Interact (2017) 278:65-73. doi: 10.1016/j.cbi.2017.10.013

145. Lee SH, Kim YS, Lee SJ, Lee BC. The Protective Effect of Salvia Miltiorrhiza in an Animal Model of Early Experimentally Induced Diabetic Nephropathy. J Ethnopharmacol (2011) 137(3):1409-14. doi: 10.1016/j.jep.2011.08.007

146. Yue KK, Lee KW, Chan KK, Leung KS, Leung AW, Cheng CH. Danshen Prevents the Occurrence of Oxidative Stress in the Eye and Aorta of Diabetic Rats Without Affecting the Hyperglycemic State. J Ethnopharmacol (2006) 106(1):136-41. doi: 10.1016/j.jep.2005.12.026

147. Tomé-Carneiro J, Larrosa M, González-Sarrías A, Tomás-Barberán FA, García-Conesa MT, Espín JC. Resveratrol and Clinical Trials: The Crossroad From In Vitro Studies to Human Evidence. Curr Pharm Des (2013) 19(34):6064-93. doi: 10.2174/13816128113199990407

148. Ramirez-Garza SL, Laveriano-Santos EP, Marhuenda-Munoz M. Storniolo CE, Tresserra-Rimbau A, Vallverdu-Queralt A, Et al. Health Effects of Resveratrol: Results From Human Intervention Trials. Nutrients (2018) 10 (12):1-18. doi: 10.3390/nu10121892

149. Mauvais-Jarvis F. Is Estradiol a Biomarker of Type 2 Diabetes Risk in Postmenopausal Women? Diabetes (2017) 66(3):568-70. doi: 10.2337/ dbi16-0063

150. Muka T, Nano J, Jaspers L, Meun C, Bramer WM, Hofman A, et al. Associations of Steroid Sex Hormones and Sex Hormone-Binding Globulin With the Risk of Type 2 Diabetes in Women: A PopulationBased Cohort Study and Meta-Analysis. Diabetes (2017) 66(3):577-86. doi: $10.2337 / \mathrm{db} 16-0473$

151. Hilborn E, Stål O, Jansson A. Estrogen and Androgen-Converting Enzymes $17 \beta$-Hydroxysteroid Dehydrogenase and Their Involvement in Cancer: With a Special Focus on $17 \beta$-Hydroxysteroid Dehydrogenase Type 1, 2, and Breast Cancer. Oncotarget (2017) 8(18):30552-62. doi: 10.18632/oncotarget.15547

152. Stupans I, Stretch G, Hayball P. Olive Oil Phenols Inhibit Human Hepatic Microsomal Activity. J Nutr (2000) 130(9):2367-70. doi: 10.1093/jn/ 130.9.2367

153. Yu PL, Pu HF, Chen SY, Wang SW, Wang PS. Effects of Catechin, Epicatechin and Epigallocatechin Gallate on Testosterone Production in Rat Leydig Cells. J Cell Biochem (2010) 110(2):333-42. doi: 10.1002/ jcb.22541

154. Banerjee B, Chakraborty S, Chakraborty P, Ghosh D, Jana K. Protective Effect of Resveratrol on Benzo(a)Pyrene Induced Dysfunctions of Steroidogenesis and Steroidogenic Acute Regulatory Gene Expression in Leydig Cells. Front Endocrinol (2019) 10:272. doi: 10.3389/ fendo.2019.00272

155. Banerjee B, Nandi P, Chakraborty S, Raha S, Sen PC, Jana K. Resveratrol Ameliorates Benzo(a)Pyrene-Induced Testicular Dysfunction and Apoptosis: Involvement of P38 MAPK/ATF2/iNOS Signaling. J Nutr Biochem (2016) 34:17-29. doi: 10.1016/j.jnutbio.2016.04.003

156. Sharma P, Aslam Khan I, Singh R. Curcumin and Quercetin Ameliorated Cypermethrin and Deltamethrin-Induced Reproductive System Impairment in Male Wistar Rats by Upregulating the Activity of Pituitary-Gonadal Hormones and Steroidogenic Enzymes. Int J Fertil Steril (2018) 12(1):7280. doi: 10.1055/s-0034-1382471

157. Rajan RK, SS M, Balaji B. Soy Isoflavones Exert Beneficial Effects on Letrozole-Induced Rat Polycystic Ovary Syndrome (PCOS) Model Through Anti-Androgenic Mechanism. Pharm Biol (2017) 55(1):242-51. doi: 10.1080/13880209.2016.1258425

158. Hu GX, Zhao BH, Chu YH, Zhou HY, Akingbemi BT, Zheng ZQ, et al. Effects of Genistein and Equol on Human and Rat Testicular 3beta-Hydroxysteroid Dehydrogenase and 17beta-Hydroxysteroid Dehydrogenase 3 Activities. Asian J Androl (2010) 12(4):519-26. doi: 10.1038/aja.2010.18

159. Santangelo C, Filesi C, Varì R, Scazzocchio B, Filardi T, Fogliano V, et al. Consumption of Extra-Virgin Olive Oil Rich in Phenolic Compounds Improves Metabolic Control in Patients With Type 2 Diabetes Mellitus:
A Possible Involvement of Reduced Levels of Circulating Visfatin. J Endocrinol Invest (2016) 39(11):1295-301. doi: 10.1007/s40618-016-0506-9

160. Lasa A, Miranda J, Bulló M, Casas R, Salas-Salvadó J, Larretxi I, et al. Comparative Effect of Two Mediterranean Diets Versus a Low-Fat Diet on Glycaemic Control in Individuals With Type 2 Diabetes. Eur J Clin Nutr (2014) 68(7):767-72. doi: 10.1038/ejcn.2014.1

161. Konstantinidou V, Khymenets O, Covas MI, de la Torre R, Muñoz-Aguayo D, Anglada R, et al. Time Course of Changes in the Expression of Insulin Sensitivity-Related Genes After an Acute Load of Virgin Olive Oil. Omics (2009) 13(5):431-8. doi: 10.1089/omi.2008.0085

162. Nakaishi Y, Bando M, Shimizu H, Watanabe K, Goto F, Tsuge H, et al. Structural Analysis of Human Glutamine:fructose-6-phosphate Amidotransferase, a Key Regulator in Type 2 Diabetes. FEBS Lett (2009) 583(1):163-7. doi: 10.1016/j.febslet.2008.11.041

163. Lindsley JE, Rutter J. Nutrient Sensing and Metabolic Decisions. Comp Biochem Physiol Part B Biochem Mol Biol (2004) 139(4):543-59. doi: 10.1016/j.cbpc.2004.06.014

164. Zhang H, Jia Y, Cooper JJ, Hale T, Zhang Z, Elbein SC. Common Variants in Glutamine:fructose-6-phosphate Amidotransferase 2 (GFPT2) Gene Are Associated With Type 2 Diabetes, Diabetic Nephropathy, and Increased GFPT2 mRNA Levels. J Clin Endocrinol Metab (2004) 89(2):748-55. doi: 10.1210/jc.2003-031286

165. Robinson KA, Sens DA, Buse MG. Pre-Exposure to Glucosamine Induces Insulin Resistance of Glucose Transport and Glycogen Synthesis in Isolated Rat Skeletal Muscles. Study of Mechanisms in Muscle and in Rat-1 Fibroblasts Overexpressing the Human Insulin Receptor. Diabetes (1993) 42(9):1333-46. doi: 10.2337/diab.42.9.1333

166. Hebert LFJr., Daniels MC, Zhou J, Crook ED, Turner RL, Simmons ST, et al. Overexpression of Glutamine:fructose-6-phosphate Amidotransferase in Transgenic Mice Leads to Insulin Resistance. J Clin Invest (1996) 98 (4):930-6. doi: 10.1172/JCI118876

167. Shetty AK, Salimath PV. Reno-Protective Effects of Fenugreek (Trigonella Foenum Greacum) During Experimental Diabetes. Eur e-Journal Clin Nutr Metab (2009) 4(3):e137-e42. doi: 10.1016/j.eclnm.2009.02.002

168. Paarakh P. In Silico Antidiabetic Activity of Linalool Isolated From Coriandrum Sativum Linn Fruit. Int J Cancer Cell Biol Res (2018) 2(1):2-6.

169. Neelakantan N, Narayanan M, de Souza RJ, van Dam RM. Effect of Fenugreek (Trigonella Foenum-Graecum L.) Intake on Glycemia: A Meta-Analysis of Clinical Trials. Nutr J (2014) 13:7. doi: 10.1186/14752891-13-7

170. Gong J, Fang K, Dong H, Wang D, Hu M, Lu F. Effect of Fenugreek on Hyperglycaemia and Hyperlipidemia in Diabetes and Prediabetes: A MetaAnalysis. J Ethnopharmacol (2016) 194:260-8. doi: 10.1016/j.jep.2016.08.003

171. Jiang H, Khan S, Wang Y, Charron G, He B, Sebastian C, et al. SIRT6 Regulates TNF-alpha Secretion Through Hydrolysis of Long-Chain Fatty Acyl Lysine. Nature (2013) 496(7443):110-+. doi: 10.1038/nature12038

172. Zhang X, Khan S, Jiang H, Antonyak MA, Chen X, Spiegelman NA, et al. Identifying the Functional Contribution of the Defatty-Acylase Activity of SIRT6. Nat Chem Biol (2016) 12(8):614-+. doi: 10.1038/ nchembio. 2106

173. Mostoslavsky R, Chua KF, Lombard DB, Pang WW, Fischer MR, Gellon L, et al. Genomic Instability and Aging-Like Phenotype in the Absence of Mammalian SIRT6. Cell (2006) 124(2):315-29. doi: 10.1016/j.cell. 2005.11.044

174. Zhong L, D'Urso A, Toiber D, Sebastian C, Henry RE, Vadysirisack DD, et al. The Histone Deacetylase Sirt6 Regulates Glucose Homeostasis Via Hif1 Alpha. Cell (2010) 140(2):280-93. doi: 10.1016/j.cell.2009.12.041

175. Dominy JE Jr, Lee Y, Jedrychowski MP, Chim H, Jurczak MJ, Camporez JP, et al. The Deacetylase Sirt6 Activates the Acetyltransferase GCN5 and Suppresses Hepatic Gluconeogenesis. Mol Cell (2012) 48(6):900-13. doi: 10.1016/j.molcel.2012.09.030

176. Le L. Computational Study of Antidiabetic Activities of Bioactive Compounds in Zingiber Officinale. World J Pharm Pharm Sci (2014) 3 (6):1995-2011.

177. Rahmatullah M, Hasan SK, Ali Z, Rahman S, Jahan R. Antihyperglycemic and Antinociceptive Activities of Methanolic Extract of Euphorbia Thymifolia L. Whole Plants. Zhong xi yi jie he xue bao $=J$ Chin Integr Med (2012) 10(2):228-32. doi: 10.3736/jcim20120213 
178. Nguyen Vo TH, Tran N, Nguyen D, Le L. An in Silico Study on Antidiabetic Activity of Bioactive Compounds in Euphorbia Thymifolia Linn. SpringerPlus (2016) 5(1):1359. doi: 10.1186/s40064-016-2631-5

Conflict of Interest: The authors declare that the research was conducted in the absence of any commercial or financial relationships that could be construed as a potential conflict of interest.
Copyright (c) 2021 Ramírez-Alarcón, Victoriano, Mardones, Villagran, Al-Harrasi, Al-Rawahi, Cruz-Martins, Sharif-Rad and Martorell. This is an open-access article distributed under the terms of the Creative Commons Attribution License (CC BY). The use, distribution or reproduction in other forums is permitted, provided the original author(s) and the copyright owner(s) are credited and that the original publication in this journal is cited, in accordance with accepted academic practice. No use, distribution or reproduction is permitted which does not comply with these terms. 